\title{
Mutluluk ve Yaşam Memnuniyetinin Belirleyicileri: Türkiye İstatistik Kurumu Yaşam Memnuniyeti Araştırması Üzerine Analizler
}

\section{Determinants of Happiness and Life Satisfaction: The Life Satisfaction Survey of the Turkish Statistical Institute}

\section{Sema Ulutürk Akman' ${ }^{1}$ (D)}

Öz

iktisat biliminin temel ilgi alanı insan ve buna bağlı olarak bireylerin ve toplumun refahı, esenliği ve iyi olmalarıdır. Dolayısıyla, söz konusu unsurları ölçmek ve zaman içinde seyrini izlemek iktisat bilimi açısından önemlidir. Bu amaçla önceleri salt ekonomik göstergeler kullanılmış, refahın ölçülmesinde hem nesnel hem öznel unsurlara yer verilmesi gerektiğinin benimsenmesi ile de insanların yaşam koşullarında sağlanan iyileşmeleri dikkate alan ölçülere intiyaç duyulmuştur. Toplumsal refahın mutluluk ve yaşam memnuniyeti üzerinden tanımlanmasıyla ölçemediğiniz şeyi yönetemezsiniz sözü uyarınca, mutluluk ve yaşam memnuniyetinin nasıl ölçüleceği konusu gündeme gelmiş ve bu alanda pek çok çalışma yapılmıştır. Türkiye İstatistik Kurumu tarafindan gerçekleştirilen Yaşam Memnuniyeti Araştırması da bu alanda yapılan çalışmalardan biridir. Çalışmanın konusunu, 2019 yılı Yaşam Memnuniyeti Araştırmasının mikro veri seti kullanılarak fertlerin demografik özelliklerinin, aylık hane halkı gelir memnuniyeti ve refah düzeyi algısının, sosyal hayat ve konut memnuniyetinin, kendisine ayırabildiği zamandan ve bireysel sağlığından duyduğu memnuniyetin mutluluk ve yaşam memnuniyeti üzerinde etkisinin ikili lojistik regresyon yöntemiyle analizi oluşturmaktadır. Bu amaçla yaşam memnuniyetini açıklamak üzere kurulan lojistik regresyon modeline göre kadınların yaşam memnuniyetinin erkeklere kıyasla daha yüksek olduğu, eğitim düzeyi arttıkça yaşam memnuniyetinin de arttı̆̆ı yaş ilerledikçe yaşamdan memnun olma oranının göreceli olarak yükseldiği, algılanan refah seviyesinin de yaşam memnuniyeti üzerinde etkili olduğu ve algılanan refah düzeyindeki artş̧a bağlı olarak yaşamdan duyulan memnuniyetin de arttı̆ı belirlenmiştir. Ayrıca, aylık hane halkı gelir memnuniyetinin, yaşanılan konuttan duyulan memnuniyetin, sosyal yaşam memnuniyetinin, bireysel anlamda beden sağlığı memnuniyetinin ve fertlerin kendilerine ayırabildiği zamana yönelik duydukları memnuniyetin de yaşam memnuniyet oranını arttırdığı belirlenmiştir. Fertlerin yaşam memnuniyetini açıklamak üzere kurulan modelden farklı olarak mutluluğu açıklamak üzere kurulan modelde eğitim değişkeninin fertlerin mutluluğu üzerinde anlamlı bir etkisinin bulunmadığı tespit edilmiştir. Mutluluk için kurulan modele göre kadınların erkeklere kıyasla daha mutlu oldukları, evli bireylerde mutlu olma oranının

1 Sorumlu Yazar: Sema Ulutürk Akman (Doç. Dr.), İstanbul Üniversitesi, İktisat Fakültesi, Ekonometri Bölümü, İstanbul, Türkiye. E-posta: akmans@istanbul.edu.tr ORCID: 0000-0002-4075-8313

Atıf: Uluturk-Akman, S. (2021). Mutluluk ve Yaşam Memnuniyetinin Belirleyicileri Türkiye İstatistik Kurumu Yaşam Memnuniyeti Araştırması Üzerine Analizler. Journal of Social Policy Conferences, 81, 35-69.

https://doi.org/10.26650/jspc.2021.81.986105 
bekarlara kıyasla daha fazla olduğu, yaş ilerledikçe mutlu olma oranının genel olarak azaldığı, refah seviyesine yönelik algının mutluluk oranını etkilediği ve refah algısı arttkça mutlu olma oranının da arttğı anlaşılmaktadır. Öte yandan, aylık hane halkı gelir memnuniyetinin, yaşanılan konuttan duyulan memnuniyetin, sosyal yaşam memnuniyetinin, bireysel anlamda beden sağlığı memnuniyetinin ve fertlerin kendilerine ayırabildiği zamana yönelik duydukları memnuniyetin de mutluluk oranını arttırdığı belirlenmiştir. Ayrıca söz konusu değişkenlerin mutluluk üzerindeki etkisinin yaşam memnuniyetinden daha fazla olduğu da tespit edilmiştir.

\title{
Anahtar Kelimeler
}

Mutluluk, Yaşam Memnuniyeti, Yaşam Kalitesi, Lojistik Regresyon Analizi, Nitel Tercih Modelleri, Sınırlı Bağımlı Değişken Modelleri

Jel Sınıflaması: C25, I31, J10

\begin{abstract}
The main focus area of economic science is the welfare and well-being of individuals in society. This requires measuring factors and monitoring their progress over time. Previous researchers used only economic indicators for this purpose; however, with the understanding that both objective and subjective elements must be included in measuring welfare, measurements that considered improvements in people's living conditions were needed. Following the adage that it is not possible to manage what cannot be measured, researchers who defined social welfare through happiness and life satisfaction undertook considerable efforts to measure these variables. The Turkish Statistical Institute's Life Satisfaction Survey is one such initiative. The purpose of this study was to measure the effects of demographic characteristics on happiness and life satisfaction. To achieve this purpose, data from the 2019 Life Satisfaction Survey, monthly household income satisfaction, perceived welfare level, social life and housing satisfaction, and time and personal health satisfaction were tested using binary logistic regression. Logistic regression findings from the model that tested life satisfaction established that women showed higher life satisfaction than did men and that life satisfaction increased with increasing age, education, and perceived wellbeing. Overall, life satisfaction increased with higher levels of welfare. Furthermore, satisfaction with the monthly household income, social life, individual physical health, and the time that individuals can spare for themselves also has a positive impact on the life satisfaction rate. Unlike in the life satisfaction model, education level had no significant effect on happiness in the model for testing happiness. In that model, women were happier than men, married respondents were happier than single respondents, and happiness generally decreased with age, but happiness increased with higher perceived well-being. Happiness also increased as satisfaction increased with monthly household income, residence, social life, individual physical health, and time to spare for oneself. In addition, the effects of these variables on happiness were greater than their effects on life satisfaction.
\end{abstract}

\section{Keywords}

Happiness, Life Satisfaction, Quality of Life, Logistic Regression Models, Qualitative Response Models, Limited Dependents Models

JEL Codes: C25, I31, J10 


\section{Extended Summary}

The main area of interest of economics is the welfare and well-being of individuals in society. Therefore, it is important in economics to measure these factors and monitor their progress over time. In this context, an increase in the per capita portion of a country's total economic activities can measurably improve welfare and is considered an important tool in this field. However, measuring welfare using purely economic indicators such as growth rate or national income per capita considers only the objective dimension of welfare and neglects the subjective dimension, and focusing only on the objective dimension means that elements money cannot buy are not accounted for in the measurement. In fact, researchers have determined that life satisfaction is critical in assessing the public's welfare where life satisfaction comprises components such as life expectancy, education, environmental quality, access to information, health, security, political participation, and work and leisure time. Factoring in both objective and subjective components of well-being is a more accurate approach to measuring welfare.

Following the criticisms of the traditional approach to measuring social welfare from solely an economic perspective, tracking indicators such as national income, growth, employment, inflation, individual income, consumption, public expenditures, income distribution, social security and social policies, academics began to realize that improving countries' economic performance and development levels needed to include improving the living conditions of people on the ground. By this argument, economic growth should be a tool for improving people's lives, and not a goal in itself, and growth should show demonstrable benefits for people's happiness and life satisfaction.

Pursuant to the argument that it is not possible to manage what cannot be measured, researchers have made active efforts to define and measure social welfare using indicators such as happiness, quality of life, and life satisfaction. The Turkish Statistical Institute launched one such effort in 2003, the Life Satisfaction Survey, an annual study of Turkish citizens' well-being. The goal of this study was to analyze the effects of demographic characteristics and individual components of quality of life on overall happiness and life satisfaction using binary logistic regression on the microdata from the 2019 Life Satisfaction Survey.

In the logistic regression model findings for the model with life satisfaction, life satisfaction was higher for Turkish women than for men, increased with 
age and education level, and it was affected by perceived well-being. Overall life satisfaction increased with satisfaction with individual quality of life components such as monthly household income, accommodations, social life, individual physical health, and time available to spend on oneself. In short, life satisfaction increases with higher individual indicators of welfare.

Unlike in the life satisfaction model, education level showed no significant effect in the model established to explain happiness. In that model, the women were happier than the men, married people were happier than single people, and happiness generally decreased with age but increased with perceived wellbeing. 


\section{Mutluluk ve Yaşam Memnuniyetinin Belirleyicileri: Türkiye İstatistik Kurumu Yaşam Memnuniyeti Araştırması Üzerine Analizler}

Dünya üzerinde var olduğu günden bu yana, daha mutlu ve daha iyi koşullarda yaşam sürdürmek insanoğlunun temel hedefleri arasında yer almıştır. Hâl böyle olunca daha iyi ve daha mutlu yaşamın nasıl mümkün olacağı konusu üzerinde çok düşünüldüğü, tartışıldığı, yazıldığı, nitekim gerek bireysel gerekse kamusal anlamda mutluluk ve yaşam memnuniyetini arttırmak üzerine çeşitli çalışmalar ve araştırmalar yapıldığı görülür.

Mutluluk ve yaşam memnuniyeti kavramları, çok sayıda faktörün etkisi ve bileşimi altında ortaya çıkan bütünsel ya da bütünleşik kavramlardır. Bu sebeple, mutluluk genel anlamda bir iyi oluş hâli ile ifade edilirken yaşam memnuniyeti dendiğinde sağlı, güvenlik, ekonomik koşullar, sosyal ilişkiler, aile bağları ve arkadaşlık ilişkileri vb. pek çok unsuru içinde barındıran kısaca yaşama yönelik tüm alanlarda iyi ve tatmin edici bir hayat sürdürmek ifade edilmektedir. Dolayısıyla mutluluk ve yaşam memnuniyeti pek çok unsuru ve özelliği içinde barındıran son derece kompleks kavramlardır.

Şüphesiz insan bireysel düzeyde ve aile düzeyinde daha iyi koşullarda ve daha mutlu yaşamın nasıl mümkün olacağı konusunda düşünerek daha iyi eğitim almak, daha iyi bir iş sahibi olmak, daha iyi kazanç elde etmek, daha sağlıklı bir bedene sahip olmak, sağlıklı beslenmek, sağlıklı yaşam sürmek, ihtiyaç duyduğunda daha nitelikli sağlık hizmeti almak, daha iyi ve güvenli bir çevrede, daha iyi ilişkiler içinde yaşamını sürdürmek vb. pek çok alanda yaşam koşullarını iyileştirmenin yöntemlerini aramaktadır.

Günümüzde insanın daha mutlu ve yaşamından daha memnun olarak hayatını sürdürmesi kamu politikasının da önemli amaçlarından birini oluşturmaktadır. Nitekim, geleneksel anlayışa göre kişi başına millî gelir seviyesi ile ölçülen toplumsal refah anlayışı günümüzde yerini mutluluk ve yaşam memnuniyetine bırakmış ve böylelikle, iktisat ve maliye politikalarının da temel hedeflerinden biri insanların daha mutlu yaşaması ve sürdürdüğü yaşamdan memnuniyet duyması olmuştur.

Toplumsal refahın mutluluk ve yaşam memnuniyeti üzerinden tanımlanmasıyla “Ölçemediğiniz şeyi yönetemezsiniz.” sözü uyarınca, mutluluk ve yaşam memnuniyetinin nasıl ölçüleceği konusu gündeme gelmiş ve bu alanda pek çok çalışma yapılmıştır. Türkiye İstatistik Kurumu tarafından 2003 yılından 
itibaren her y1l düzenli olarak gerçekleştirilen ve sonuçları açıklanan Yaşam Memnuniyeti Araştırması da bu alanda yapılan araştırmalardan biridir.

Çalışma kapsamında toplumsal refah göstergesi olarak mutluluk ve yaşam memnuniyeti kavramlarına ilişkin temel düzeyde açıklamalar yapılarak mutluluk ve yaşam memnuniyetini ölçmeye yönelik Türkiye İstatistik Kurumu tarafindan gerçekleştirilen Yaşam Memnuniyeti Araştırmasından bahsedilecek ve söz konusu araştırmanın 2019 yılı mikro veri seti üzerinden fertlerin mutluluk ve yaşam memnuniyetleri üzerinde etkili olan faktörler lojistik regresyon yöntemiyle analiz edilecektir.

\section{Refah Göstergesi Olarak Mutluluk ve Yaşam Memnuniyeti}

Geleneksel iktisadi yaklaşıma göre, toplumun refah seviyesini arttırmak birey ve ailelerin gelirlerinin artması ile mümkün kabul edilmiş, birey ve ailelerin gelirinde sağlanan artışın onlara daha çok harcama imkânı yaratacağ 1 ve böylelikle birey ve ailelerin daha iyi yaşam sürdürmek için gerekli olan koşulları finanse edebilir hâle geleceği öngörülmüş̧ür. Nitekim toplumsal refah seviyesini belirlemede ve izlemede ekonomik büyüme ve kişi başına millî gelir artışını dikkate alan yaklaşımın da temel dayanağını bu varsayım oluşturmuştur. Oysa, adil bir gelir dağılımı koşulu altında sağlanmamış kişi başına millî gelir artışının, düşük gelir grubunun yoksullaşmasına ve buna bağlı olarak daha kötü yaşam koşullarında hayatlarını sürdürmek zorunda kalmasına sebep olacağ 1 buna karşılık, yüksek gelir grubunun ise koşullarını daha da iyileştirmesine yol açabileceği görülmüş ve kişi başına millî gelir artışının refah ölçüsü olarak kullanılmasına yönelik çekinceler ortaya çıkmıştır.

Sosyal bilimler çatısı altında yer alan iktisat biliminin temel ilgi alanı insan ve buna bağlı olarak bireylerin refahı, esenliği ve iyi olmalarıdır. Dolayısıyla, söz konusu unsurları ölçmek ve zaman içinde seyrini izlemek iktisat bilimi açısından önemlidir. Bu bağlamda bir ülkede gerçekleştirilen iktisadi faaliyetlere yönelik toplam parasal büyüklüğün kişi başına düşen kısmında artış sağlanması refahın maddi, nesnel ve ölçülebilir boyutuna katkı sağlama potansiyeli taşımakta ve bu alanda önemli bir araç olarak değerlendirilmektedir. Ancak refahın parasal bir büyüklük vasıtasıyla bu şekilde ölçümü, refahın sadece nesnel boyutunu dikkate almakta öznel boyutunu ise ihmal etmektedir. Refahı sadece nesnel boyutuyla değerlendirmek, paranın satın almada yetersiz kalacağ 1 ya da doğrudan parayla satın alınamayacak bazı unsurların refah ölçümünde 
dikkate alınmaması anlamı taşır. Dolayısıyla kişi başına gelir yanında, yaşam memnuniyeti, yaşam süresi, eğitim süresi, çevre kalitesi, bilgiye erişim, sağl1k, güvenlik, siyasal katılım, iş ve boş zaman gibi pek çok kriter dikkate alınarak yapılacak refah ölçümü hem nesnel hem öznel değerlendirmeye imkân tanıyacağından, daha doğru bir yaklaşım olarak değerlendirilecektir (Güneş vd., 2018: 3).

Refahın ölçülmesinde hem nesnel hem öznel unsurlara yer verilmesi gerektiğinin benimsenmesi ve toplumsal refahın ölçüsü olarak ekonomik boyutu dikkate alan geleneksel yaklaşıma yöneltilen eleştiriler sonucunda, ülkelerin gelişme ve kalkınma seviyelerini belirlemek üzere iktisadi performansı dikkate alan büyüme hızı ya da kişi başına millî gelir gibi salt ekonomik göstergeler yerine insanların yaşam koşullarında sağlanan iyileşmeleri dikkate alan ölçülere ihtiyaç duyulmuştur. Bu anlayışa göre, iktisadi büyüme bir amaç olmayıp insanların yaşamlarını geliştiren bir araç olarak ele alınmalı ve iktisadi büyümenin sağladığı faydanın insanın yaşam kalitesine ve yaşam memnuniyetine ne ölçüde yansıdığı belirlenmeye çalışılmalıdır.

$\mathrm{Bu}$ anlamda, önce insani gelişme kavramı ve insani gelişme endeksi kullanılmış ve böylelikle refah yaşam standardı yaklaşımıyla ölçülmeye çalışılmıştır. Zaman içinde ekonomik anlamda daha iyi standartlarda yaşamdan daha insanca yaşam hedefine geçilmiş böylelikle mutluluk ve yaşam memnuniyeti bir refah unsuru olarak iktisadın alanına girmiştir.

Mutluluk ile iktisat arasındaki bağlantının bireysel ve toplumsal olduğu kadar ülke düzeyinde gerçekleşen faaliyetlerle de ilişkilendirildiği görülür. $\mathrm{Bu}$ bağlamda mutluluk, millî gelir, büyüme, istihdam enflasyon, bireysel gelir, tüketim, kamu harcamaları, gelir dağılımı, sosyal güvenlik ve sosyal politikalar ile ilişkili bir kavramdır ve sayılan tüm bu başlıklar doğrudan iktisadın konusunu oluşturmaktadır. Öte yandan mutluluk üzerinde etkili olduğu bilinen bu ana unsurlar içinde kamu gelirleri ve vergileme, kamu harcamaları, gelir dă̆ılımı, sosyal güvenlik ve sosyal politikalar, yönetişim ve kamu kurumları kamu ekonomisi alanında değerlendirilmektedir (Şeker, 2016: 75 ve 95).

Şüphesiz, toplumların refah seviyelerini belirlemede sadece ekonomik göstergeleri dikkate almak eksik bir değerlendirme olacaktır. Toplumları insanlar oluşturduğuna göre refah ölçümlerinde insan boyutu da mutlaka dikkate alınmalı ve insanların sürdürdükleri yaşamlarına yönelik değerlendirmeleri 
sorgulanmalıdır. Bu noktada karşımıza öznel iyi olma hâli, mutluluk, memnuniyet, yaşam kalitesi, yaşam memnuniyeti ve yaşam doyumu gibi pek çok kavram çıkmaktadır.

Tüm insanların yaşamları boyunca ulaşmaya çabaladığı mutluluk kavramına yönelik, pek çok disiplin alanında mutluluk temalı çalışmalar yapılmasına ve disiplinler arası çalışmalara da konu olmasına rağmen üzerinde uzlaşılmış tek bir tanımının bulunmadığ 1 görülmektedir. Kavramın, tek bir tanıma indirgenememesi ve pek çok farklı tanım kullanılarak açıklanmaya çalışılmasının temel sebebi belki de disiplinler arası bir kavram olması ve her disiplinin kendi alanında bir tanım geliştirme çabası içinde bulunmasıdır.

Genel olarak bakıldığında, öznel iyi olma hâlinin mutlulukla eş anlamlı kullanıldığ1 ve bu manada mutluluğun, bireyin sürdürmekte olduğu yaşama yönelik kişisel değerlendirmesi olarak tanımlandığı anlaşılmaktadır (Bozcuk ve Öz, 2018: 4733; akt. Aydın, 2020: 136). Dolayısıyla mutluluk, bireylerin sürdürdükleri yaşama yönelik öznel değerlendirmeleri sonucunda ortaya çıkmaktadır.

Mutluluk kavramı, bireyin, bir bütün olarak değerlendirdiğinde, hayatından zevk alma düzeyi olarak tanımlanmaktadır. Bu bağlamda mutluluk, bireyin tüm yaşamına yönelik bir değerlendirmeyi ifade etmekte ve bireylerin akıllarında şekillendirdikleri tüm unsurları içermektedir. Dolayısıyla bireyin nasıl hissettiği, beklentilerinin ne kadarının karşılanabildiği gibi tüm unsurlar söz konusu tanım içinde yer almaktadır (Vatansever ve Yıldız, 2017: 233).

Mutluluk, başlangıçta insanın duygu ve algı dünyasıyla ilgili bir kavram olarak ele alınmış ve bu bağlamda psikolojinin ilgi alanı içinde değerlendirilmiştir. Ancak mutluluk üzerine araştırma ve analizler arttıkça konunun sadece psikoloji ile değil, pek çok bilim dalıyla ilgili son derece girift bir kavram olduğu anlaşılmıştır. Mutluluğun iktisat bilimiyle ilişkili bir kavram olduğunu gösteren ilk çalışmanın Easterlin'in 1974 yılında yayınladığı makale olduğu kabul edilmektedir. Söz konusu makale, gelişmiş ve gelişmekte olan toplam 19 ülkeye uygulanmış bir araştırmaya dayanmakta ve başlıca iki analiz içermektedir. $\mathrm{Bu}$ bağlamda önce ülke düzeyinde insanların gelirleri ile mutluluk seviyeleri arasında ilişki olup olmadığına bakılarak gelir ile mutluluk arasında pozitif bir ilişki saptanmış ve en yüksek gelire sahip grubun, en düşük gelire sahip gruba kıyasla neredeyse iki kat daha fazla mutlu olduğu tespit edilmiştir. Araştırmada 
ayrıca zengin ülkelerdeki ortalama mutlulukla zengin olmayan ülkelerdeki ortalama mutluluk seviyeleri de karşılaştırılmış ve iki grup arasında anlamlı bir farklılık olmadığı belirlenmiştir. Dolayısıyla daha yüksek gelir seviyesine sahip zengin ülkelerdeki mutluluk ortalamasının düşük gelir seviyesine sahip ülkelerle aynı olduğu kabul edilmiştir. Bu bağlamda, çalışmanın birinci sonucu ile iki sonucu arasındaki çelişki literatüre Easterlin Paradoksu olarak geçmiştir (Karabulut, 2017: 89-90).

Mutluluk ile gelir arasındaki ilişkiyi araştıran çok sayıda çalışma yapılarak bireyin mutluluk anlayışının ortalama gelire göre farkl1lık gösterebileceği sonucuna ulaş1lmakla beraber görüşün günümüzde eskisi kadar kabul görmediği anlaşılmaktadır. Bu bağlamda mutluluk fayda olarak değerlendirildiğinde, yoksul bireylerin daha fazla fayda potansiyeline sahip oldukları kabul edilmektedir. Örneğin, yetersiz beslenmeye maruz kalan kişilerin yaşamlarında gerçekleşecek en küçük bir iyileşme kendilerine fayda sağlayacak ve mutluluk getirecektir. Bu sebeple gelir seviyesi insanların mutluluk seviyesini doğrudan etkilemekle beraber tek başına bir mutluluk kaynağı olarak açıklanamamaktadır (Akgiş, 2015, s. 70).

Mutluluğun fayda yaklaşımıyla değerlendirilmesiyle beraber insanların hayat standartlarındaki artışın mutluluk üzerinde etkili olduğu kabul edilerek mutluluk ile iktisat arasında bir bağlantı kurulmuş ve mutluluk ekonomisi adı altında bir iktisat alanı yaratılarak iktisatçılar bu alanda araştırma ve çalışmalar yapmaya başlamışlardır. İktisat literatüründe yeni bir alan olarak karşımıza çıkan mutluluk ekonomisinin, refah iktisadı, kalkınma iktisadı ve davranışsal iktisat ile ilişkili olduğu kabul edilmektedir. Öte yandan, refah ekonomisi ve davranışsal iktisat içinde mutluluk olgusunun yerini fayda olgusunun alması gerektiği tartışılırken gelişme iktisadında ise mutluluk, gelişmişlik düzeyinin bir göstergesi olarak değerlendirmektedir. Bu çerçeve içinde uygulamalı çalışmalarla gelişen bir alan olarak ele alınan mutluluk ekonomisi, mutluluğun iktisadi belirleyicilerini bir araç olarak kullanarak mutluluk seviyesini yükseltmeye yönelik ekonomik politikalar geliştiren bir iktisat alanıdır (Çevik, Altınkeski ve Kantarcı, 2019, s. 183).

Öte yandan, mutluluğun belirleyicilerinin neler olduğu üzerine yapılan pek çok çalışma sonucunda mutluluğun; demografik faktörlerle, ekonomik, sosyal, kültürel ve fiziksel çevre koşullarıyla, yaşanılan ülkenin sosyoekonomik koşullarıyla ilişkili olduğu kabul edilmiştir. Dolayısıyla mutluluk çok sayıda faktörün etkisi altında ortaya çıkan, başka bir deyişle pek çok faktörün bileşimi 
sonucunda vücut bulan iyi hissetme veya iyilik hâlidir. Bu açıdan bakıldığgnda doğrudan yaşamın kendisiyle ilgili pek çok faktöre göre şekillenen mutluluk, yaşam memnuniyetiyle ilişkilendirilmektedir.

Mutluluk ve memnuniyet kavramlarının birbiriyle ilişkili olduğu ve birbirlerini karşılıklı olarak etkiledikleri kabul edilmektedir. Bu bağlamda mutlu olmanın memnun olmak; memnun olmanın ise mutlu olmak sonucunu doğurduğu varsayılmaktadır. Sürdürülen yaşamdan duyulan memnuniyet açısından bakıldığında da bireyin yaşam kalitesine yönelik genel değerlendirmesi sonucunda ulaşılan olumluluk derecesi ve duyulan haz yaşam memnuniyet düzeyini ifade etmektedir. Başka bir deyişle bireylerin yaşamdan aldıkları hazzın ne derece gerçekleştiği şeklinde tanımlayabileceğimiz yaşam memnuniyetinin sürdürülen yaşam kalitesine bağlı olarak ortaya çıktığı kabul edilmektedir (Veenhoven, 1996: 17). Bu bağlamda yaşam kalitesi, insanların biyolojik durumları, yaşam biçimleri, ilişkileri ve içinde bulundukları çevrenin nicel ve nitel değerlerinin toplamı olarak tanımlanabilir. Bütünsel bir bakış açısıyla değerlendirildiğinde yaşamın tüm boyutlarının üstün nitelikli olması, kaliteli yaşamı olanaklı kılar. Bu çerçevede yaşam kalitesi ile yaşam standardı farklı kavramlardır. Yaşam standardı; toplumlara, sınıflara, dönemlere göre değişkenlik gösteren, bireylerce tüketilen mal ve hizmet miktarı olarak açıklanabilir ve satın alma gücü paritesine göre kişi başına düşen millî gelir yaşam standardına yönelik verilebilecek en iyi örneklerden biridir. Yaşam doyumu ya da yaşam memnuniyeti ise, kişinin beklentileri karşısında yaşam kalitesi unsurlarından elde ettiği hislerle ilgili bir karşılaştırmadır ve mutluluktan daha somut temellere dayandığı kabul edilir. Bireyin yaşam memnuniyeti üzerinde etkili olan faktörler yaş, sağlık, stres, yaşam şekli ve kişilik özellikleri (Chow, 2005: 140) sosyal ilişkiler, başarı, doğa ile ilgili uğraşılar, cinsel faaliyet, beslenme türü, kitap okuma ve müzik dinleme gibi aktiviteler (Dockery, 2003: 4) şeklinde sıralanabilir (Şeker, 2011: 117).

Daha önce de ifade ettiğimiz gibi mutluluk genel olarak öznel iyi olma hâli olarak tanımlanmaktadır. Bu tanımdan yola çıkarak önce öznel iyi olma hâlini ve öznel iyi olma durumunu oluşturan bileşenleri açıklayalım.

Mutlulukla bağlantılı öznel iyi olma hâli; olumlu-olumsuz duygulanım, kişisel yargı ve yaşam doyumu olmak üzere üç bileşenin etkisi altında ortaya çıkan bir durum olarak nitelenir (Diener, 1985:71-75). Kavramın öznel 
(sübjektif) nitelik taşıması bireysel değerlendirmeye göre belirlenmesi ve kişiden kişiye farklılık göstermesiyle ilgilidir. Başka bir deyişle öznel iyi olma kavramı, bireylerin yaşamlarındaki olumlu duyguların çokluğu buna karşılık olumsuz duyguların azlığı ve bu bağlamda yaşamları ile ilgili yaptıkları bilişsel değerlendirme olarak tanımlanmaktadır (Diener vd., 2003: 405). Burada sözü edilen olumlu-olumsuz duygulanım neşe, eğlence, acı, öfke gibi iyilik hâlinin duygusal boyutunu, yaşam doyumu ise iyilik hâlinin bilişsel boyutunu temsil etmektedir (Diener, 1984:542). Dolayısıyla, öznel iyi olma hâlinin iyileştirilmesi, söz konusu boyutları oluşturan unsurlar açısından bireylerin desteklenmeleri ile mümkün olmaktadır. Öte yandan bu konuda yapılan çalışmalarda yaşam doyumu ve yaşam kalitesi kavramlarının eş anlamlı kullanımına rastlanmakla beraber, yaşam kalitesi nesnel ve öznel kriterlere dayanırken; yaşam doyumu öznel değerlendirmeyi esas almaktadır. Bu yaklaşım yaşam doyumunun öznelliğinin de göstergesidir (Arslan ve Bektaş, 2019:769).

Bu bağlamda, bireyin ve dolayısıyla toplumun iyi olma hâli pek çok faktörün etkisi altında gerçekleşmektedir. Son derece karmaşık ve çok sayıda faktöre bağlı olan bu iyi olma hâli genel bir kavram olarak yaşam memnuniyetiyle ilişkilendirilmektedir.

Bu konuda karşımıza çıkan bir diğer kavram da yaşam kalitesidir. Yaşam kalitesinin, çok geniş kapsamlı ve disiplinler arası bir kavram olması sebebiyle tek bir tanımı yapılamamaktadır.

Dünya Sağlık Örgütü yaşam kalitesini tanımlamaya yönelik iki yaklaşım benimsemektedir. Bu tanımlardan ilki yaşam kalitesini bireylerin hayat içindeki durumlarını, ait oldukları kültürel yapı ve değerler sistemi bağlamında algılama ve değerlendirme biçimi olarak ele alır. Şüphesiz sözü edilen değerlendirme işlemi bireylerin beklentileri, hedefleri, yaşam standartları ve hayata ilişkin kaygılarıyla ilişkili olarak gerçekleştirilmektedir. Diğer tanım ise, yaşam kalitesini bireyin fiziksel sağlı̆̆1, psikolojik durumu, özgürlük seviyesi, sosyal ilişkileri ve yaşadığı çevrenin başlıca özellikleriyle etkileşimi gibi çok sayıda faktöre bağlı olarak şekillenen, karmaşık ve geniş bir kavram olarak nitelendirir (Bıçk1, 2015:161).

Başka bir deyişle yaşam kalitesi, barınma, istihdam, gelir, maddi refah, ahlaki tutumlar, kişisel ve aile yaşamı, sosyal destek, stres ve kriz, sağlık hayatına ilişkin yaşam kalitesi, sağlık hizmetleri, çalışma koşulları, beslenme, eğitim 
olanakları, ekolojik faktörler vb. olarak şeklinde sıralanabilecek birçok faktörden ve durumdan etkilenmektedir (Dalia, 2007: 44).

Öte yandan yaşam kalitesinin, çevre kalitesi, yaşanabilirlik ve sürdürülebilirlik gibi kavramlarla da ilişkili olduğu kabul edilmektedir. Bu bağlamda çevresel kalite, çevrenin sahip olduğu fiziksel, sosyal ve sembolik özellikleriyle, barındırdığı nüfusa ve kullanıcılarına huzur, refah ve memnuniyet duygusu verme potansiyeli olarak değerlendirilmektedir (Bıçkı, 2015:162)

Yaşanabilirlik kavramı ise, bir yerleşim yerinde yaşayan insanların tüm koşullarının değerlendirilmesi ve ölçülmesine yönelik parametreler bütünü olarak ifade edilir. Bu bağlamda insanların temel ve üst düzey ihtiyaçlarının karşılanma biçimi, kendilerine sağlanan insani gelişme olanakları yaşanabilirlik kavramının çerçevesini oluşturmaktadır. Dolayısıyla halk sağlığının korunduğu, emniyet ve güvenlik koşullarının sağlandığı, toplumsal bütünleşme, çeşitlilik ve kültürel kimliğin geliştirildiği, doğal, tarihî, dinî ve kültürel bakımdan anlamlı yapı ve bölgelerin korunduğu yerleşim alanlarının iyi yaşam kalitesine sahip olduğu kabul edilmektedir (Parlak, 2011:3; akt. Tandoğan, 2014: 20).

Sürdürülebilirlik kavramı da yaşam kalitesiyle bağlantılı önemli kavramlardan biridir. Sürdürülebilirlik kavramı, insanın ekonomik, çevresel ve toplumsal gereksinimlerinin gelecek kuşakların yaşam koşullarına zarar vermeden karşılanmasını hedefleyen bir anahtar kavram ya da dünya görüşü olarak değerlendirilmektedir (Oktay, 2007). Dolayısıyla, sürdürülebilirlik kavramı bir duyarlılık göstergesidir ve insanların yaşam kalitesini yükseltmek amaçlanırken gelecek kuşakları da göz önüne almak gerektiğine vurgu yapmaktadır.

Buna bağlı olarak yaşam doyumunu, söz gelimi iktisatçılar ekonomik iyi olma hâli (economic well-being) ya da net ekonomik refah, psikologlar veya sosyal psikologlar genel iyilik hâli, yaşam doyumu, genel mutluluk şeklinde tanımladığı görülmektedir. Öte yandan bireyin yaşam kalitesi üzerinden mutluluk tanımı da yapılabilmektedir. Buna göre, mutluluk, bireyin yaşam kalitesini genel olarak değerlendirmesi sonucunda ulaştı̆̆ olumluluk derecesi olarak tanımlanmaktadır (Veenhoven, 1989: 22-25; akt. Bektaş, 2015: 92 ve 96). Tanımdan da anlaşılacağı gibi, mutluluk bireyin yaşam kalitesine yönelik bir değerlendirmedir. Benzer şekilde yaşam memnuniyetinin de yaşam kalitesi anlamında kullanılan bir kavram olduğu görülmektedir. Bu bağlamda yaşam memnuniyeti (life satisfaction), bireyin kendi yaşam kalitesini tümüyle 
değerlendirmesi neticesinde ulaştığı olumluluk derecesi olarak tanımlanmaktadır (Veenhoven, 1996:17).

Bireyin yaşam kalitesini değerlendirmesi sonucunda belirlediği olumluluk derecesi biçiminde tanımlanan mutluluk ve memnuniyet kavramlarının birbirine çok yakın anlamları olduğu ve bu sebeple söz konusu iki kavramın birbirinin eş anlamlı karşılığı olarak kullanıldığı anlaşılmaktadır. Dolayısıyla, mutluluk ve yaşam memnuniyeti kavramlarının genel olarak aynı anlamda değerlendirildiği, yaşam kalitesinin ise mutluluk ve yaşam memnuniyetini belirleyici bir kavram olarak söz konusu iki kavramın önceleyeni olduğu kabul edilmektedir (Bektaş, 2015: 97).

Yukarıdaki açıklamalardan da görüldüğü gibi toplumsal refah düzeyinin göstergesi olarak mutlulukla bağlantılı çok sayıda kavram karşımıza çıkmakta ve yaşam memnuniyeti, yaşam doyumu, yaşam kalitesi ve öznel iyi oluş kavramları mutlulukla yakından ilgili kavramlar olarak değerlendirilmektedir. Bu çalışma ile özellikle Türkiye İstatistik Kurumu Yaşam Memnuniyeti Araştırması'na odaklanıldığından, mutluluk ve memnuniyet kavramlarına yönelik söz konusu araştırmaya esas tanımlara da yer verilmiştir. Buna göre, Türkiye İstatistik Kurumu'nun (TÜİK) Yaşam Memnuniyeti Araştırması kapsamında mutluluk, acı, keder ve 1stırabın yokluğu; bunların yerine sevinç, neşe ve tatmin duygularının varlığıyla karakterize edilen durum ve hayattan genel olarak memnun olma hâli; memnuniyet ise, ihtiyaçların ve isteklerin karşılanmasından doğan tatmin duygusu olarak tanımlanmaktadır.

Ekonomik anlamda refah göstergesi olarak kullanıldığında mutluluk ve yaşam memnuniyeti kavramlarının birbirine çok yakın anlamlar ifade ettiği ve bireylerin genel olarak yaşam kalitelerini değerlendirmeleri sonucunda mutluluk ve yaşam memnuniyeti düzeylerini belirledikleri söylenebilir. Bu açıdan yaşam memnuniyeti ve mutluluk, yaşam kalitesine göre belirlenen iyi oluş hâlidir ve bu iyi oluş hâli aynı zamanda bir refah göstergesi olarak kullanılmaktadır.

Mutluluk kavramının refah ölçüsü olarak ele alınması, iktisat alanında mutluluk ekonomisi adında yeni bir alan oluşması sonucunda mutluluk temalı çalışmalar ve araştırmalar artmıştır. Mutluluk kavramına yönelik ölçüm ve analizler 1940'lı yıllarda başladığ 1 ve ilerleyen zamanlarda konuya ilginin artmasıyla beraber gerek sağlık, psikoloji ve sosyal bilimler alanlarında gerekse çok disiplinli alanlarda bu konuda çalışmalar yapıldığı görülmektedir. Dünya 
Mutluluk Raporu, Mutlu Gezegen Endeksi, Dünya Mutluluk Veri Tabanı ve Dünya Değerler Araştırması, çok sayıda ülkeyi kapsamaları açısından mutluluk alanında ilk akla gelen araştırma ve çalışmalardır.

Mutluluğun nasıl ölçüleceğine yönelik araştırmalardan biri de Türkiye İstatistik Kurumu tarafindan bireylerin genel mutluluk algısını, toplumsal değerlerini, temel yaşam alanlarındaki genel memnuniyetini ve kamu hizmetlerinden memnuniyetini ölçmek ve bu memnuniyet düzeylerinin zaman içindeki değişimini izlemek amacıyla gerçekleştirilen Yaşam Memnuniyeti Araştırmasıdır.

Türkiye İstatistik Kurumu Yaşam Memnuniyeti Araştırmasıında mutluluk kavramının, bireyin yaşam koşullarını belirleyen demografik, ekonomik, fiziksel çevre, sosyal çevre, içinde yaşanılan ülkenin durumu gibi çok sayıda bileşenden oluştuğu kabul edilmekte ve bu bağlamda mutluluk ve memnuniyet derecelerinin belirlenmesinde bireylerin nesnel yaşam koşulları yanında öznel algılarına da yer verilmesi gerektiği ifade edilmekte ve bunun sonucu olarak bireysel düzeyde mutluluk ve memnuniyet kavramlarının iç içe geçtiği belirtilmektedir ( Şeker, 2011:117).

\section{Metodoloji ve Bulgular}

Türkiye İstatistik Kurumu'nun Yaşam Memnuniyeti Araştırması'yla ${ }^{{ }^{*}}$ bireylerin genel mutluluk algısını, toplumsal değerlerini, temel yaşam alanlarındaki genel memnuniyetini ve kamu hizmetlerinden memnuniyetini ölçmek ve bu memnuniyet düzeyinin zaman içinde değişimini takip etmek amaçlanmakta ve araştırma 2003 yılından bu yana ülke genelinde düzenli olarak gerçekleştirilmektedir ${ }^{2 *}$. 2003-2012 yılları arasında araştırmanın örneklem büyüklüğünde kır-kent bazında ayrıma gidildiği ve buna bağlı olarak yaşam memnuniyetiyle ilgili kır ve kent bazlı tahminler üretildiği görülmektedir. 2013 yılında ise kır-kent ayrımından vazgeçildiği ve araştırmanın örneklem büyüklüğünün, Türkiye İstatistik Kurumu İstatistiki Bölge Birimleri Sınıflaması 3. Düzey bazında yani 81 il düzeyinde tahminler üretecek şekilde kurgulandığ 1 ancak bu yaklaşımın sadece bir yıl geçerli olduğu anlaşılmaktadır. 2014 yılından

$1^{*}$ Yaşam Memnuniyeti Araştırması'na ilişkin bilgiler için bkz: TÜiK Yaşam Memnuniyeti Araştırması Mikro Veri Seti-2020, Yayın No: 4618, Mayıs 2021, https:/www.tuik.gov.tr/media/microdata/pdf/yasammemnuniyeti-arst.pdf

2* 2003 Yılı Yaşam Memnuniyeti Araştırması Hane Halkı Bütçe Anketine ek bir modül olarak uygulanmıştır. https://www.tuik.gov.tr/media/microdata/pdf/yasam-memnuniyeti-arst.pdf 
bu yana araştırmada Türkiye düzeyinde tahminler üretecek şekilde bir yaklaşım benimsendiği ve örneklem büyüklüğünün de buna göre tasarlandığ1 görülmektedir. Yaşam Memnuniyeti Araştırması kapsamında mutluluk, yaşam memnuniyet düzeyi, temel yaşam alanlarındaki memnuniyet, eğitim, sağlık, asayiş, adli, ulaştırma, belediye/il özel idare hizmetlerinden memnuniyet, çevre güvenliği, umut düzeyi, toplumsal baskı algısı gibi çeşitli konulara yer verilmekte ve katılımcıların söz konusu konulara yönelik oluşturulmuş sorulara verdikleri cevaplar değerlendirilmektedir.

Yaşam Memnuniyeti Araştırmasında iki aşamalı tabakalı küme örneklemesi yöntemi kullanılmakta ve birinci aşamada ortalama 100 haneden oluşan kümeler (bloklar) örneğe seçilmekte, ikinci aşamada ise örneğe seçilen kümelerden sistematik seçim yöntemi kullanılarak örnek adresler belirlenmektedir. Öte yandan Yaşam Memnuniyeti Araştırmasının örneklem birimi hane, gözlem birimi ise hane içinde yaşamını sürdüren 18 veya daha yukarı yaşa sahip bireylerdir. Buna bağlı olarak araştırmada iki ayrı soru formu kullanılmakta ve böylelikle hane düzeyinde ve fert düzeyinde veri toplama işlemi gerçekleştirilmektedir. Öte yandan, yaşam memnuniyeti araştırmasında hane halkı düzeyinde uygulanan soru formu 6 ana başlıkta toplam 72 sorudan; fert düzeyinde uygulanan soru formu ise 7 ana başlık altında toplanan 246 sorudan oluşmaktadır.

Türkiye İstatistik Kurumu Yaşam Memnuniyeti Araştırmasında kullanılan anket formunda fertlerin mutluluk ve yaşam memnuniyetini belirlemeye yönelik iki soru dışında mutluluk ve yaşam memnuniyetiyle bağlantılı çeşitli sorular ve ayrica demografik sorular yer almaktadır.

Daha önce de ifade edildiği gibi mutluluk ve yaşam memnuniyeti bireylerin içinde yaşadıkları sosyal, kültürel ve ekonomik koşullarla ve demografik özelliklerle ilgilidir. Bu bağlamda, mutluluk ve yaşam memnuniyetinin, fertlerin demografik özellikleri yanında, sağlıkla, sosyal ve kültürel yaşamla ilgili olarak sosyal hayat, kendine ayırabildiği zamandan duyulan memnuniyetle, ekonomik koşullarla ilgili olarak da aylık hane geliri ve yaşanılan konuttan duyulan memnuniyetle ve algılanan refah düzeyi ile ilişkisi lojistik regresyon modelleriyle belirlenmiştir.

Çalışmada 2019 yılında gerçekleştirilen Yaşam Memnuniyeti Araştırmasının fert düzeyinde mikro veri seti kullanılmıştır. Araştırma 9212 kişi ile gerçekleştirilmiş ve katılımcıların demografik bilgileri Tablo 1'de gösterilmiştir. 
Tablo 1

Fert Düzeyinde Katılımcıların Demografik Özellikleri

\begin{tabular}{|l|l|c|c|}
\hline Değişken & Değişken Düzeyleri & Frekans & \% \\
\hline \multirow{5}{*}{ Cinsiyet } & Erkek & 4226 & 45,9 \\
\cline { 2 - 4 } & Kadın & 4986 & 54,1 \\
\hline \multirow{5}{*}{ Yaş grubu } & $18-24$ & 1059 & 11,5 \\
\cline { 2 - 4 } & $25-34$ & 1813 & 19,7 \\
\cline { 2 - 4 } & $35-44$ & 1955 & 21,2 \\
\cline { 2 - 4 } & $45-54$ & 1714 & 18,6 \\
\cline { 2 - 4 } & $55-64$ & 1352 & 14,7 \\
\cline { 2 - 4 } & $65+$ & 1319 & 14,3 \\
\hline \multirow{5}{*}{ Medeni Durum } & Hiç evlenmedi & 1597 & 17,3 \\
\cline { 2 - 4 } & Evli & 6702 & 72,8 \\
\cline { 2 - 4 } & Boşand1 & 302 & 3,3 \\
\cline { 2 - 4 } & Eşi öldü & 611 & 6,6 \\
\hline \multirow{5}{*}{ Eğitim Durumu } & Okul bitirmedi & 1260 & 13,7 \\
\cline { 2 - 4 } & İlkokul & 1385 & 32,4 \\
\cline { 2 - 4 } & Ortaokul & 1827 & 19,0 \\
\cline { 2 - 4 } & Lise & 1780 & 17,2 \\
\cline { 2 - 4 } & Fakülte/yüksekokul & 1,9 \\
\cline { 2 - 4 } & Lisansüstü (5-6 y1llik fakülte dahil) & 178 & \\
\hline
\end{tabular}

Araştırmaya katılan 9212 kişiden \%45,9'u erkek, \%54,1'i kadın olup \%17,3'ü hiç evlenmemiş, \%72,8'i evli, \%3,3'ü boşanmış ve \%6,6'sı ise eşi vefat etmiş kimselerdir. Yaş grubuna bakıldığında, katılımcıların \%11,5'i 1824, \%19,7'si 25-34, \%21,2'si 35-44, \%18,6's1 45-54, \%14,7'si 55-64 ve \%14,3'ü de $65+$ yaş grubunda yer almaktadır.

Katılımcıların eğitim durumlarına bakıldığında 1260 kişinin hiç okul bitirmediği anlaşılmaktadır. Öte yandan katılımcıların \%32,4'ünün ilkokul, \%15'inin ortaokul, \%19,8'inin lise, \%17,2'sinin fakülte/yüksekokul, \%1,9'unun da 5-6 yıllık fakülte ya da lisansüstü derecelerden mezunu olduğu görülmektedir. Demografik değişkenlerin tüm düzeyleri için yeterli sayıda gözlem mevcuttur.

\section{Yöntem}

Mutluluk ve yaşam memnuniyeti üzerine yapılan araştırmalar genel olarak değerlendirildiğinde, mutluluk ve yaşam memnuniyetinin tek bir faktörle açıklanamadığı, zaman ve mekân içinde değişimler gösteren, öncelikleri 
farklılaşan ve yer değiştiren birçok faktöre bağlı olarak ortaya çıkan bir olgu şeklinde ele alındığı görülmektedir (Şeker ve Bektaş, 2019:139). Bu noktadan hareketle, fertlerin mutluluk ve yaşamından memnun olup olmamaları üzerinde cinsiyet, medeni durum, yaş, eğitim durumu yanında hane halkı gelirine yönelik memnuniyet, yaşanılan konuta yönelik memnuniyet, sosyal hayat, sağlık ve fertlerin kendine ayırabildikleri zaman konularında duydukları memnuniyetin etkisi lojistik regresyon modelleriyle analiz edilmiştir. Lojistik regresyon analizi, çalışma kapsamında detaylı biçimde ele alınmamış, uygulanan modellerin daha kolay anlaşı1masını sağlamak açısından yöntemi kısaca tanıtmakla yetinilmiştir (Lojistik regresyon modelleriyle ilgili ayrıntılı bilgi için bkz: Ulutürk Akman, 2014: 134-139; Ulutürk Akman: 2017: 313-315).

Lojistik regresyon modelleri bağımlı değişkeninin kategorik değişken olması hâlinde kullanılan regresyon analizi yöntemidir. Lojistik regresyon analizinde bağımlı değişken kategorik değişken niteliği taşımakta, bağımsız değişkenler ise kategorik olabileceği gibi sürekli değişken de olabilmektedir.

Öte yandan nitel tercih modelleri ya da kesikli tercih modelleri olarak da adlandırılan lojistik regresyon modellerinde bağımlı değişken, mutlu-mutsuz gibi ikili kategorik (binary ya da dikotomik) değişken olabileceği gibi, düşükorta-yüksek memnuniyet düzeyi gibi sıralı ve tercih edilen siyasi parti gibi çok düzeyli de olabilir.

Lojistik regresyon modellerinde en çok benzerlik yöntemi kullanılarak parametreler tahmin edilmekte ve modelin başarısı veya uygunluğu ise belirginlik katsayısı yanında parametrelerin ve modelin test edilmesiyle sınanmaktadır.

Klasik regresyonda modelin bağımlı değişkendeki değişmelerin ne kadarını açıklayabildiği, modelin uyum iyiliği açısından önemli bir kriterdir. Bu bağlamda, lojistik regresyon analizinde modelin açıklama gücü Cox-Snell R-kare ve Nagelkerke R-kare katsayılarıyla değerlendirilir. Ancak, lojistik regresyon analizinde R-kare değerinin klasik regresyon analizinde olduğu gibi yüksek değer alması beklenmez. Dolayısıyla, lojistik regresyon analizinde modelin açıklama yüzdesini gösteren R-kare değerinin klasik regresyona kıyasla oldukça düşük çıkması göz önüne alınması gereken önemli hususlardan biridir. Bu bakımdan, iki düzeyli lojistik regresyon modellerinde, uyum iyiliği ölçülerinin ikincil öneme sahip olduğu ve asıl dikkat edilmesi gereken noktanın regresyon katsayılarının 
beklenen işaretleri ve istatistiksel anlamlılıkları olduğu kabul edilmektedir (Gujarati, D., çev: Bolatoğlu, N., 2016: 238). Bu bağlamda tahmin edilen parametrelere yönelik anlamlılık testleri özellikle önem taşımaktadır.

Klasik regresyon analizinde, modelde yer alan parametrelerin anlamlılık sınaması $\mathrm{t}$ testi ile gerçekleştirilirken lojistik regresyonda Wald testi kullanılmaktadır. Modelde yer alan parametrelerin, ilgili bağımsız değişken ile bağımlı değişken arasındaki ilişkiyi gösteriyor olması sebebiyle Wald testi sonucunda sıfirdan farklı olduğunun kabul edilmesi son derece önemlidir. Aksi hâlde, yani, parametrenin değerinin sıfır olduğu kabul edildiğinde bağımsız değişken ile bağımlı değişken arasında istatistik açıdan anlamlı bir ilişki bulunmadığına karar verilmiş olur ki bu durumda söz konusu değişkenin modelde yer almaması gerekecektir.

Lojistik regresyonda modelin genel anlamda anlamlılı̆̆ını sınamada ise Hosmer-Lemeshow testi kullanılmaktadır. Gözlenen frekanslar ile modele göre tahmin edilen frekanslar arasındaki uyumu test etmeyi amaçlayan HosmerLemeshow testinin temel hipotezi gözlenen ve beklenen frekansların uyumlu olduğu şeklindedir. Dolayısıyla söz konusu teste yönelik anlamlılık düzeyinin 0,05 'ten büyük olması durumunda gözlenen ve beklenen frekansların uyumlu olduğu şeklinde kurulan temel hipotez reddedilemeyecek ve modelin uygun olduğuna karar verilecektir.

Modelin uygunluğuna yönelik kullanılacak diğer bir kriter de doğru sınıflama oranıdır. Lojistik regresyon yöntemi bağımsız değişken / değişkenlerin değerlerine bağlı olarak bağımlı değişkenin atanacağı kategoriyi belirlemeyi amaçlar. Dolayısıyla lojistik regresyon yöntemi birimleri, bağımsız değişkenlerin aldığı değerlere göre bağımlı değişkenin kategorilerine atar. Doğru sınıflama oranı da bu atama işleminin ne ölçüde doğru yapıldığını belirleyen bir ölçüttür.

Lojistik regresyon analiziyle ilgili bir diğer önemli husus ise model ile tahmin edilen parametrelerin değil, odds oranlarının (odds ratio) yorumlanmasıdır. Odds oranı $[\operatorname{Exp}(\beta i)]$, bağımlı değişkenin, i. bağımsız değişkenin etkisiyle kaç kat daha fazla gözlenme olasılığına sahip olduğunu gösterir. Odds oranının 1'e yakın değerleri, ilgili bağımsız değişkenin bağımlı değişken üzerinde önemli bir etkiye sahip olmadığını gösterirken, 1 değerinin çok üzerindeki değerler pozitif bir etkinin, 1'in altındaki değerler ise negatif bir etkinin var olduğunu ifade etmektedir (Karagöz, 2015: 608). 


\section{Bulgular}

Yaşam Memnuniyeti Araştırmasında fertlerin mutluluk düzeyini belirlemeye yönelik soru; çok mutlu, mutlu, orta, mutsuz ve çok mutsuz olmak üzere 5 düzeyli Likert ölçeğine göre kurgulanmış, yaşam memnuniyetini belirlemeye yönelik soru ise 1-11 aralığında bir ölçek üzerinden sorgulanmıştır. Mutluluk, sosyal hayat, konut, sağlık, aylık hane geliri, kendine ayırdığı zaman memnuniyetini ölçmeye yönelik sorularda da 5'li Likert ölçeği kullanılmıştır. Çalışma kapsamında 5 düzeyli Likert ölçekli tüm sorular iki düzeyli olacak şekilde yeniden kodlanmış mutluluk sorusunun cevap düzeyleri mutlu değil-mutlu; memnuniyet sorularının cevap düzeyleri ise memnun değil-memnun şeklinde isimlendirilmiştir. Algılanan refah düzeyine yönelik sorunun cevap düzeyleri 1-4 aralığg için düşük, 5-7 aralığı için orta, 8-11 aralığı için yüksek refah seviyesi olarak yeniden kodlanarak 3 düzeyli forma dönüştürülmüştür. Yaşam memnuniyeti sorusu ise 1-5 aralığındaki cevaplar memnun değil, 6-11 aralığı ise memnun şeklinde iki düzeyli olarak düzenlenmiştir.

Buna göre, fertlerin mutluluğunu belirlemeye yönelik değişken düzeyleri, mutsuz- 0 ve mutlu-1; yaşam memnuniyetini belirlemeye yönelik değişken düzeyleri de memnun değil-0 ve memnun -1 biçiminde kodlanmış ve böylelikle iki düzeyli (binary) lojistik regresyon modellerine uygun hâle getirilmiştir.

Daha önce de ifade edildiği gibi lojistik regresyon analizinde odds oranı yorumu özellikle önem taşımaktadır. İki düzeyli lojistik regresyon analizinde tahmin edilen odds oranları, bir değişkenin iki farklı düzeyini bağımlı değişkenin iki düzeyi açısından kıyaslamaya yarayan bir değerdir. Buradaki uygulama açısından bakıldığında, değişken düzeyleri için hesaplanan odds oranları, bağımlı değişkenin değerinin 0'dan 1'e geçmesi üzerinde söz konusu bağımsız değişken düzeyinin ne kadar etkili olduğunu göstermektedir. Örneğin, mutluluk üzerinde demografik faktörlerin etkisini belirlemek amacıyla kurulan lojistik regresyon modelinde cinsiyet değişkeninin kadın düzeyinde odds oranı 1,5 tahmin edilmişse, kadınlarda mutlu olma oranının mutsuz olmaya kıyasla erkeklerden 1,5 kat daha fazla olduğu anlaşılmaktadır.

Aşağıda, mutluluk ve yaşam memnuniyeti üzerinde, cinsiyet medeni durum, yaş, eğitim durumu, sağlık, sosyal hayat, kendine ayırabildiği zaman, yaşanılan konut, aylık hane gelirinden duyulan memnuniyet ve algılanan refah seviyesi 
etkisini belirlemeye yönelik oluşturulan iki lojistik regresyon modelinin sonuçları ve yorumları verilmektedir.

\section{Fertlerin Yaşamlarından Memnun Olup Olmamaları Üzerinde Demografik} Faktörler ile Sosyokültürel ve Ekonomik Faktörlere Yönelik Algıların Etkisi

Fertlerin yaşamlarından memnun olup olmamaları üzerinde demografik faktörlerin ve sosyokültürel ve ekonomik faktörlere yönelik algıların etkisini analiz etmek üzere oluşturulan lojistik regresyon modelinin sonuçları ve uyum iyiliği ölçüleri Tablo 2'de gösterilmiştir.

Tablo 2

Yaşam Memnuniyeti Üzerinde Demografik Sosyal ve Ekonomik Faktörlerin Etkisi

\begin{tabular}{|c|c|c|c|c|c|}
\hline Değişken Düzeyleri & & $\begin{array}{c}\text { Standart } \\
\text { Hata }\end{array}$ & $\begin{array}{c}\text { Wald } \\
\text { İstatistiği }\end{array}$ & $\begin{array}{c}\text { Anlamlılık } \\
\text { Düzeyi }\end{array}$ & $\begin{array}{c}\text { Odds } \\
\text { Oranı } \\
\operatorname{Exp}\left(\boldsymbol{\beta}_{i}\right)\end{array}$ \\
\hline Cinsiyet /Kadın & 0,238 & 0,056 & 18,378 & 0,000 & 1,269 \\
\hline Medeni Durum & & & 39,943 & 0,000 & \\
\hline Evli & 0,216 & 0,092 & 5,535 & 0,019 & 1,241 \\
\hline Boşand 1 & $-0,477$ & 0,160 & 8,853 & 0,003 & 0,620 \\
\hline Eşi öldü & $-0,175$ & 0,144 & 1,479 & 0,224 & 0,839 \\
\hline Eğitim Durumu & & & 105,067 & 0,000 & \\
\hline İlkokul & 0,544 & 0,084 & 42,106 & 0,000 & 1,722 \\
\hline Ortaokul & 0,696 & 0,104 & 44,688 & 0,000 & 2,006 \\
\hline Lise & 0,944 & 0,102 & 86,551 & 0,000 & 2,571 \\
\hline Fakülte/Yüksekokul & 0,938 & 0,105 & 79,733 & 0,000 & 2,556 \\
\hline Lisansüstü & 0,926 & 0,233 & 15,744 & 0,000 & 2,525 \\
\hline Yaş grubu & & & 11,038 & 0,051 & \\
\hline $25-34$ & 0,079 & 0,109 & 0,521 & 0,471 & 1,082 \\
\hline $35-44$ & 0,272 & 0,120 & 5,171 & 0,023 & 1,313 \\
\hline $45-54$ & 0,096 & 0,124 & 0,602 & 0,438 & 1,101 \\
\hline $55-64$ & 0,164 & 0,129 & 1,602 & 0,206 & 1,178 \\
\hline $65+$ & 0,298 & 0,139 & 4,584 & 0,032 & 1,348 \\
\hline Refah & & & 746,558 & 0,000 & \\
\hline Orta & 1,248 & 0,058 & 470,532 & 0,000 & 3,485 \\
\hline Yüksek & 2,651 & 0,114 & 538,339 & 0,000 & 14,171 \\
\hline Konut memnuniyeti & 0,226 & 0,081 & 7,858 & 0,005 & 1,254 \\
\hline Sosyal hayat memnuniyeti & 0,404 & 0,068 & 35,034 & 0,000 & 1,499 \\
\hline Sağl1k memnuniyeti & 0,433 & 0,074 & 34,028 & 0,000 & 1,542 \\
\hline
\end{tabular}




\begin{tabular}{|l|c|c|c|c|c|}
\hline Aylık hane gelir memnuniyeti & 0,466 & 0,057 & 66,761 & 0,000 & 1,594 \\
\hline Kendine zaman ayırma & 0,134 & 0,071 & 3,564 & 0,059 & 1,143 \\
\hline Sabit parametre & $-2,421$ & 0,159 & 231,436 & 0,000 & 0,089 \\
\hline \multicolumn{7}{|c|}{ Cox-Snell R-kare değeri: 0,192 } \\
\hline Nagelkerke R-kare değeri: 0,274 \\
Doğru sınıflama oran1: \%76,2 \\
\hline
\end{tabular}

Fertlerin yaşam memnuniyeti üzerinde cinsiyet, medeni durum ve eğitimden oluşan demografik değişkenlerin ve sosyokültürel ve ekonomik algıyı ölçen değişkenlerin etkisini analiz etmek üzere kurulan modelin uyum iyiliği kriterlerine ve test sonuçlarına bakıldığında modelin bağımlı değişkeni açıklama oranının Nagelkerke R-kare değerine göre \%27,4 seviyesinde olduğu görülmektedir. Bu değer lojistik regresyon analizi için iyi sayılabilecek bir açıklama oranını ifade etmektedir. Modele alınmamış faktörlerin, fertlerin hissettikleri baskı üzerinde etkisi ise yaklaşık \%72,5 düzeyindedir.

Modelin doğru sınıflama oranı \%76,2'dir. Dolayısıyla kurulan lojistik regresyon modeli vasıtasıyla, modelde yer alan bağımsız değişkenlere yönelik değişken düzeyleri kullanılarak fertlerin yaşam memnuniyetinin, memnun ve memnun değil şeklinde kategorilere atanması \% 76,2 oranında doğru olarak gerçekleştirilmektedir.

Hosmer-Lemeshow testinin anlamlılık düzeyi 0,235 olup, bu, gözlenen ve model ile tahmin edilen frekansların uyumlu olduğu biçimindeki temel hipotezin reddedilemeyeceği anlamına gelmektedir. Dolayısıyla model; gözlenen ve beklenen frekanslar dikkate alındığında uyumludur.

Modelin açıklama oranı lojistik regresyon analizi uygulamaları açısından yüksek sayılabilecek düzeyde bulunması, test sonuçlarının başarılı olması yanında özellikle parametrelerin teker teker anlamlılığını sınayan Wald testine göre tüm değişkenlerin istatistik açıdan anlamlı kabul edilmesi sonucunda sözü edilen model başarılı kabul edilerek yorumlanmıştır.

Cinsiyet değişkeninin kadın kategorisi için tahmin edilen odds oranı 1,269'dur ve bu, kadınlarda yaşamdan memnun olma oranının erkeklerden 1,269 kat daha fazla olduğunu ifade etmektedir. 
Yaşam memnuniyeti üzerinde medeni durum da etkili bir değişkendir. Yaşam memnuniyeti araştırmasında medeni durum değişkeni hiç evlenmedi, evli, boşandı ve eşi öldü şeklinde dört düzeyli bir değişkendir. Lojistik regresyon analizinde bağımsız değişkenin ikiden fazla düzeyi ya da kategorisi olması durumunda ilk ya da son kategori referans kategori kabul edilerek modelin çözümü gerçekleştirilir ve odds oranı yorumları da tercih edilen referans kategoriye göre yapılır. Model çözümünde medeni durum değişkeni için referans kategori olarak ilk kategori yani hiç evlenmemişler kategorisi seçildiğinden, medeni durum değişkeninin diğer tüm düzeyleri için odds yorumları "hiç evlenmemişler" kategorisine kıyasla yapılacaktır.

Evliler için odds oranı 1,241 tahmin edilmiştir. Dolayısıyla evli bireylerde yaşamından memnun olma oranı hiç evlenmemişlere kıyasla yaklaşık 1,25 kat daha fazladır.

Boşanmış bireyler kategorisinde odds oranı 0,620'dir. Odds oranının 1'den küçük olması ilgili kategoride yaşamdan memnuniyet oranının referans kategoriden daha düşük olduğunun göstergesidir. Buna göre, boşanmış bireylerde yaşamdan memnun olma oranı hiç evlenmemiş bireylerin memnun olma oranının \%62'si kadardır.

Odds oranının 1'den küçük olması durumunda yorumların daha anlaşı1ır olması açısından, referans kategorinin ilgili kategoriye göre odds oranını gösteren ve 1/odds oranı ile hesaplanan odds oranının tersi tercih edilebilir. Dolayısıyla $1 / 0,620=1,61$ biçiminde hesaplanan odds oranı, boşanmış bireylere kıyasla hiç evlenmemiş bireylerde yaşamdan memnun olma oranının 1,61 kat daha fazla olduğu anlaşılmaktadır.

Eşi vefat etmiş bireyler kategorisi için tahmin edilen parametrenin Wald testi sonucunda istatistik açıdan anlamsız olduğu kabul edildiğinden söz konusu odds oranı yorumlanmamıştır.

Fertlerin eğitim düzeyleri de yaşam memnuniyetleri üzerinde etkilidir. Referans kategori olarak ilk kategori, yani okul bitirmemişler alındığından tüm yorumlamalar bu kategoriye göre yapılmıştır. Dolayısıyla, okul bitirmemişlerle kıyaslandığında ilkokul mezunları 1,722 kat, ortaokul mezunları 2,006 kat, lise mezunları 2,571 kat, fakülte/yüksekokul mezunları 2,556 kat ve lisansüstü mezunları ise 2,525 kat yaşamından daha memnun görünmektedir. 
Yaşamdan duyulan memnuniyet konusunda yaş da etkili bir değişkendir Yaşam memnuniyeti araştırmasında yaş sorusu açık uçlu olarak hazırlanmış ve uygulanmış olmakla beraber çalışma kapsamında gruplama yoluna gidilmiş ve araştırmaya katılanların yaşları, Tablo 1'de görüldüğü gibi, 6 grupta toplanmıştır. Yaş grubu 6 düzeyli bir değişken olarak çok düzeyli kategorik değişken olduğundan ilk yaş grubu olan 18-24 yaş grubu referans kategori seçilmiş ve tüm odds oranı yorumları bu kategoriye göre yapılmıştır.

Buna göre yaşamdan memnun olma oranının 18-24 yaş grubuna kıyasla, 35-44 yaş grubunda 1,313 kat; 65 + yaş grubunda ise 1,348 kat daha fazla olduğu anlaşılmaktadır. Diğer yaş grupları için tahmin edilen parametrelerin Wald testi sonucunda istatistik açıdan anlamsız olduğu kabul edildiğinden odds oranları yorumlanmamıştır.

Yaşam memnuniyeti araştırması kapsamında yer alan fertlerin ekonomik durumlarına yönelik algı düzeylerini belirlemek üzere aylık hane halkı gelir memnuniyeti ve sürdürülen yaşama yönelik refah algısı değişkenleri de yaşam memnuniyeti üzerinde etkili değişkenlerdir. Refah düzeyi, düşük, orta ve yüksek şeklinde kodlanmış ve ilk kategori olan düşük refah seviyesi referans kategori olarak seçilmiştir. Buna göre düşük refah seviyesinde yaşamını sürdürenlere kıyasla orta düzeyde refaha sahip olanlarda yaşam memnuniyeti yaklaşık 3,5 kat daha fazladır. Yüksek refah seviyesine sahip olanlarda ise yaşamdan memnuniyet oranı düşük refah seviyesine kıyasla yaklaşık 14 kat daha yüksektir. Buna göre algılanan refah seviyesi yaşamdan memnun olma açısından önemli bir değişkendir.

Aylık hane halkı gelir düzeyinden duyulan memnuniyet açısından bakıldığında, hane halkı gelirinden memnun olanlarda yaşamdan memnuniyet oran1, memnun olmayanlara kıyasla 1,594 kat daha fazladır.

Yaşanılan konuttan duyulan memnuniyet de yaşam memnuniyeti üzerinde etkili bir değişkendir. Yaşadığı konuttan memnun olanlarda yaşam memnuniyeti, yaşadığı konuttan memnun olmayanlara kıyasla 1,254 kat daha fazladır.

Sağlık da fertlerin yaşam memnuniyetini etkileyen değişkenlerdendir. Sağlığından memnun olanların yaşam memnuniyet oranı, sağlığından memnun olmayanlara kıyasla 1,542 kat daha yüksektir.

Sosyokültürel yaşamı temsil etmek üzere modele dahil edilen sosyal yaşamdan duyulan memnuniyet ve kişinin kendisine ayırabildiği zamandan 
duyduğu memnuniyet değişkenlerinin de yaşam memnuniyeti üzerinde etkili değişkenler olduğu tespit edilmiştir. Sosyal yaşamından memnun olan bireylerde yaşam memnuniyeti 1,499 kat; kendine ayırdığı zamandan memnun olanlarda ise yaşam memnuniyeti 1,143 kat daha fazladır.

\section{Fertlerin Mutlu Olup Olmamaları Üzerinde Demografik Faktörler ile Sosyokültürel ve Ekonomik Faktörlere Yönelik Algıların Etkisi}

Fertlerin mutlu olup olmamaları üzerinde demografik özelliklerinin ve sosyokültürel ve ekonomik faktörlere yönelik algılarının etkisini analiz etmek üzere oluşturulan lojistik regresyon modelinin sonuçları ve uyum iyiliği ölçüleri Tablo 3'te gösterilmiştir.

Fertlerin mutlu olup olmamaları üzerinde cinsiyet, medeni durum ve eğitimden oluşan demografik değişkenlerin ve sosyokültürel ve ekonomik algıyı ölçen değişkenlerin etkisini analiz etmek üzere kurulan modelin uyum iyiliği kriterlerine ve test sonuçlarına bakıldığında modelin bağımlı değişkeni açıklama oranının Nagelkerke R-kare değerine göre \%30,6 seviyesinde olduğu görülmektedir. Bu değer lojistik regresyon analizi için iyi sayılabilecek bir açıklama oranını ifade etmektedir. Modele alınmamış faktörlerin fertlerin hissettikleri baskı üzerinde etkisi ise yaklaşık \%70 düzeyindedir.

Modelin doğru sınıflama oranı \%88,4'tür. Dolayısıyla kurulan lojistik regresyon modeli vasıtasıyla, modelde yer alan bağımsız değişkenlere yönelik değişken düzeyleri kullanılarak fertlerin yaşam memnuniyetinin, memnun ve memnun değil şeklinde kategorilere atanması $\% 88,4$ oranında doğru olarak gerçekleştirilmektedir.

Hosmer-Lemeshow testinin anlamlılık düzeyi 0,830 olup, bu, gözlenen ve model ile tahmin edilen frekansların uyumlu olduğu biçimindeki temel hipotezin reddedilemeyeceği anlamına gelmektedir. Dolayısıyla model, gözlenen ve beklenen frekanslar dikkate alındığında uyumludur.

Modelin açıklama oranı lojistik regresyon analizi uygulamaları açısından yüksek sayılabilecek düzeyde bulunması, test sonuçlarının başarılı olması yanında özellikle parametrelerin teker teker anlamlılığını sınayan Wald testine göre tüm değişkenlerin istatistik açıdan anlamlı kabul edilmesi sonucunda sözü edilen model başarılı kabul edilerek yorumlanmıştır. 
Tablo 3

Mutluluk Üzerinde Fertlerin Demografik Özelliklerinin, Sosyokültürel ve Ekonomik Faktörlere Yönelik Algılarının Etkisi

\begin{tabular}{|c|c|c|c|c|c|}
\hline Değişken Düzeyleri & & $\begin{array}{c}\text { Standart } \\
\text { Hata }\end{array}$ & $\begin{array}{c}\text { Wald } \\
\text { İstatistiği }\end{array}$ & $\begin{array}{l}\text { Anlamlılık } \\
\text { Düzeyi }\end{array}$ & $\begin{array}{c}\text { Odds Oranı } \\
\operatorname{Exp}\left(\beta_{i}\right)\end{array}$ \\
\hline Cinsiyet /Kadın & 0,569 & 0,075 & 57,010 & 0,000 & 1,767 \\
\hline Medeni Durum & & & 114,409 & 0,000 & \\
\hline Evli & 0,679 & 0,119 & 32,621 & 0,000 & 1,972 \\
\hline Boşand 1 & $-0,545$ & 0,188 & 8,403 & 0,004 & 0,580 \\
\hline Eşi öldü & $-0,213$ & 0,189 & 1,274 & 0,259 & 0,808 \\
\hline Yaş grubu & & & 16,829 & 0,005 & \\
\hline $25-34$ & $-0,214$ & 0,148 & 2,091 & 0,148 & 0,807 \\
\hline $35-44$ & $-0,140$ & 0,162 & 0,755 & 0,385 & 0,869 \\
\hline $45-54$ & $-0,395$ & 0,165 & 5,742 & 0,017 & 0,674 \\
\hline $55-64$ & $-0,427$ & 0,172 & 6,186 & 0,013 & 0,652 \\
\hline $65+$ & $-0,017$ & 0,191 & 0,008 & 0,927 & 0,983 \\
\hline Refah & & & 252,723 & 0,000 & \\
\hline Orta & 1,031 & 0,075 & 189,828 & 0,000 & 2,804 \\
\hline Yüksek & 1,797 & 0,159 & 128,293 & 0,000 & 6,029 \\
\hline Konut memnuniyeti & 0,586 & 0,093 & 39,510 & 0,000 & 1,797 \\
\hline Sosyal hayat memnuniyeti & 0,552 & 0,090 & 37,920 & 0,000 & 1,737 \\
\hline Sağl1k memnuniyeti & 1,102 & 0,087 & 160,386 & 0,000 & 3,011 \\
\hline Aylik hane gelir memnuniyeti & 1,021 & 0,081 & 159,906 & 0,000 & 2,777 \\
\hline Kendine zaman ayırma & 0,336 & 0,089 & 14,284 & 0,000 & 1,399 \\
\hline Sabit parametre & $-1,711$ & 0,168 & 104,053 & 0,000 & 0,181 \\
\hline \multicolumn{6}{|c|}{ Cox-Snell R-kare değeri: 0,162} \\
\hline \multicolumn{6}{|c|}{ Nagelkerke R-kare değeri: 0,306 } \\
\hline \multicolumn{6}{|c|}{ Doğru sınıflama oranı: $\% 88,4$} \\
\hline \multicolumn{6}{|c|}{ Hosmer-Lemeshow Test İstatistiği: 4,293; anlamlllık seviyesi: 0,830 } \\
\hline
\end{tabular}

Cinsiyet değişkeninin kadın kategorisi için tahmin edilen odds oranı 1,767'dir ve bu, kadınlarda mutluluk oranının erkeklerden yaklaşık 1,8 kat daha fazla olduğunu ifade etmektedir.

Mutluluk üzerinde medeni durum da etkili bir değişkendir. Model çözümünde medeni durum değişkeni için referans kategori olarak ilk kategori yani hiç evlenmemişler kategorisi seçildiğinden, medeni durum değişkeninin diğer tüm düzeyleri için odds yorumları "hiç evlenmemişler" kategorisine kıyasla yapılacaktır.

Evliler için odds oranı 1,972 tahmin edilmiştir. Dolayısıyla evli bireylerde yaşamından mutluluk oranı hiç evlenmemişlere kıyasla yaklaşık 2 kat daha fazladır. 
Boşanmış bireyler kategorisinde odds oranı 0,580 'dir. Odds oranının 1'den küçük olması ilgili kategoride mutluluk oranının referans kategoriden daha düşük olduğunun göstergesidir. Buna göre, boşanmış bireylerde mutluluk oranı hiç evlenmemiş bireylerin mutluluk oranının \%58'i kadardır.

Odds oranının 1'den küçük olması durumunda yorumların daha anlaşılır olması açısından, referans kategorinin ilgili kategoriye göre odds oranını gösteren ve 1/odds oranı ile hesaplanan odds oranının tersi tercih edildiğini ifade etmiştik. Dolayısıyla 1/0,580=1,72 biçiminde hesaplanan odds oran1, boşanmış bireylere kıyasla hiç evlenmemiş bireylerde mutluluk oranının 1,72 kat daha fazla olduğu anlaşılmaktadır.

Eşi vefat etmiş bireyler kategorisi için tahmin edilen parametrenin Wald testi sonucunda istatistik açıdan anlamsız olduğu kabul edildiğinden söz konusu odds oranı yorumlanmamıştır.

Fertlerin mutlu olmaları konusunda yaş da etkili bir değişkendir. Yaş grubu çok düzeyli bir kategorik değişken olduğundan ilk yaş grubu olan 18-24 yaş grubu referans kategori seçilmiş ve tüm odds oranı yorumları bu kategoriye göre yapılmıştır.

Buna göre 45-54 yaş grubunda mutluluk oranı 18-24 yaş grubu mutluluk oranının \%67,4'ü, kadardır. 55-64 yaş grubunda mutluluk oranının ise 18-24 yaş grubundaki mutluluk oranının \%65,2'si kadar olduğu anlaşılmaktadır. Odds oranlarının 1'den küçük olması sebebiyle tersleri alınarak yorumlanması tercih edilmektedir. 18-24 yaş grubunda mutluluk oranı, 45-54 yaş grubuna kıyasla $(1 / 0,674=1,48)$ yaklaşık $1,5 \mathrm{~kat} ; 55-64$ yaş grubunda ise $(1 / 0,652=1,53)$ yaklaşı 1,5 kat daha fazladır. Diğer yaş grupları için tahmin edilen parametrelerin Wald testi sonucunda istatistik açıdan anlamsız olduğu kabul edildiğinden odds oranları yorumlanmamıştır.

Yaşam memnuniyeti araştırması kapsamında yer alan fertlerin ekonomik durumlarına yönelik algı düzeylerini belirlemek üzere aylık hane halkı gelir memnuniyeti ve sürdürülen yaşama yönelik refah algısı değişkenleri de fertlerin mutlu olup olmamaları üzerinde etkili değişkenlerdir. Algılanan refah düzeyi değişkenine ilişkin ilk kategori olan düşük refah seviyesi referans kategori olarak seçilmiştir. Buna göre düşük refah seviyesinde yaşamını sürdürenlere kıyasla orta düzeyde refaha sahip olanlarda mutluluk oranı yaklaşık 2,8 kat 
daha fazladır. Yüksek refah seviyesine sahip olanlarda ise mutluluk oranı düşük refah seviyesine kıyasla yaklaşık 6 kat daha yüksektir.

Aylık hane halkı gelir düzeyinden duyulan memnuniyet açısından bakıldığında, hane halkı gelirinden memnun olanlarda mutluluk oranı, memnun olmayanlara kıyasla 1,594 kat daha fazladır.

Yaşanılan konuttan duyulan memnuniyet de mutluluk üzerinde etkili bir değişkendir. Yaşadığı konuttan memnun olanlarda mutluluk oran, yaşadığ1 konuttan memnun olmayanlara kıyasla 1,797 kat daha fazladır.

Sağlık da fertlerin mutluluğu üzerinde etkili bir değişkenlerdendir. Sağlığından memnun olanların mutluluk oranı, sağlığından memnun olmayanlara kıyasla yaklaşık 3 kat daha yüksektir.

Sosyokültürel yaşamı temsil etmek üzere modele dahil edilen sosyal yaşamdan duyulan memnuniyet ve kişinin kendisine ayırabildiği zamandan duyduğu memnuniyet değişkenlerinin de yaşam memnuniyeti üzerinde etkili değişkenler olduğu tespit edilmiştir. Sosyal yaşamından memnun olan bireylerde mutluluk oranı 1,737 kat; kendine ayırdığ zamandan memnun olanlarda ise mutluluk oran 1 1,399 kat daha fazladır.

\section{Tartışma ve Sonuç}

İnsanoğlunun dünya üzerinde bin yıllar süren geçmişinde ilkel koşullarla başlayan ve günümüzün son derece karmaşık ve kompleks yaşam koşullarına uzanan hayat hikayesinde daha mutlu olmak, daha mutlu yaşamak üzerine gün geçtikçe daha çok düşünüldüğünü ve bu konuda araştırmalar yapıldığını görüyoruz. Modern hayat düzeni içinde sosyal bir varlık olan insan yalnızlaştıkça, hayat koşulları zorlaştıkça mutlu yaşamın sırrını çözmek, mutluluğa giden yolda insanlara rehberlik etmek ve mutlu olmanın nasıl mümkün olacağıyla ilgili çok sayıda araştırma yapıldığını, kitaplar yazıldığını ve seminerler düzenlendiğini görüyoruz.

Her ne kadar mutluluk önceleri psikoloji, felsefe ve sosyoloji ile ilgi bir kavram olarak değerlendirilse de konuya duyulan ilgiye bağlı olarak sosyal bilimler alanında da mutluluk temalı çalışmalar artmış ve gerçekleştirilen bilimsel çalışmalarda mutluluğun kaynağının nelerde olduğu sorgulanmış ve mutluluk ile ilişkili olabilecek çeşitli sosyoekonomik ve demografik göstergeler incelenmeye başlamıştır. 
Bu bağlamda, mutluluk kavramının iktisat literatürüne girişi, ülkelerin ve toplumların refah seviyelerini ölçmede ve buna bağlı olarak ülkeleri sıralama, kıyaslama ve hatta sınıflamada dikkate alınan parametrelerin zaman içinde değişimi sonucunda olmuştur. Toplumların refah seviyelerini belirlemek, zaman içinde meydana gelen değişimi izlemek ve ülkeleri kıyaslamak açısından referans alınan göstergelere bakıldığında ekonomik büyüme ve kişi başına gelir ile başlayan, insani gelişme endeksi ile devam eden ve günümüzde mutluluk kavramına ulaşan bir tarihsel süreçten geçildiği görülür.

Şüphesiz insanlar çok farklı özelliklere sahiptir ve buna bağlı olarak birbirinden farklı ihtiyaç ve beklentiler içinde yaşamlarını sürdürürler. İşte bu noktada ilk olarak refah kavramının ortaya atıldığı ve buna bağlı olarak aralarındaki tüm farklılıklara rağmen hemen her insan için geçerli olabilecek normlara dayalı bir refah tanımına ihtiyaç duyulduğu görülür.

Refah kavramının ortaya çıkmasıyla, toplumsal refah seviyesinin nasıl ölçüleceği konusunun önem kazandığı ve bu bağlamda, millî gelir ve kısaca millî gelirde meydana gelen artış olarak tanımlanan ekonomik büyüme ve daha sonra da ülkeler arası kıyaslamalar ya da sınıflamalar yapabilmek açısından kişi başına millî gelir kavramları önemli toplumsal refah göstergeleri olarak kullanılmaya başlanmıştır.

1980'li yıllardan itibaren, ülkelerin refah ve kalkınma seviyelerini ölçmede kullanılan bu geleneksel yöntemin geçerliliğine yönelik bir dizi tartışmalar başladığı ve özellikle, yaratılan gelirin toplumun değişik kesimlerine nasıl dağıldığının da dikkate alınması gerektiği vurgulanarak toplumsal refahı ölçmek amacıyla daha iyi bir ölçüm aracı geliştirmek adına alternatif yöntem arayışlarına girildiği görülür.

Refahın ölçülmesinde hem nesnel hem öznel unsurlara yer verilmesi gerektiğinin benimsenmesi ve toplumsal refahın ölçüsü olarak ekonomik boyutu dikkate alan geleneksel yaklaşıma yöneltilen eleştiriler sonucunda, ülkelerin gelişme ve kalkınma seviyelerini belirlemek üzere iktisadi performansı dikkate alan büyüme hızı ya da kişi başına millî gelir gibi salt ekonomik göstergeler yerine, insanların yaşam koşullarında sağlanan iyileşmeleri dikkate alan ölçülere ihtiyaç duyulmuştur. Bu anlayışa bağlı olarak kalkınmanın araçları ve amaçları ayrı ayrı değerlendirilmeye başlanmış ve ekonomik gelişmenin bir araç; insani gelişmenin ise bir amaç olduğu kabul edilmiştir. 
Bu anlayış çerçevesinde önce, insani gelişme kavramı ve buna bağlı olarak geliştirilen İnsani Gelişme Endeksi kullanılmış ve böylelikle refah, yaşam standardı yaklaşımıyla ölçülmeye çalışılmıştır. Ancak zaman içinde ekonomik anlamda daha iyi standartlarda yaşam mı, yoksa daha insanca yaşam mı sorusu gündeme gelmiş ve böylelikle yaşam doyumu ve mutluluk, bir refah unsuru olarak iktisadın alanına girmiştir.

Bu bağlamda mutluluk, millî gelir, ekonomik büyüme, istihdam enflasyon, bireysel gelir, tüketim, kamu harcamaları, gelir dağılımı, sosyal güvenlik ve sosyal politikalar ile ilişkili bütünleşik bir kavramdır ve sayılan tüm bu başlıklar doğrudan iktisadın konusunu oluşturmaktadır. Öte yandan mutluluk üzerinde etkili olan tüm bu ana unsurlar içinde kamu gelirleri ve vergileme, kamu harcamaları, gelir dağılımı, sosyal güvenlik ve sosyal politikalar, yönetişim ve kamu kurumları, kamu ekonomisi alanında değerlendirilmektedir.

Mutluluk kavramı bireyin, bir bütün olarak değerlendirdiğinde, hayatından zevk alma düzeyi olarak tanımlanmaktadır. Bu bağlamda mutluluk, bireyin tüm yaşamına yönelik bütünsel bir değerlendirmeyi ifade etmekte ve bireylerin akıllarında şekillendirdikleri tüm unsurları içermektedir. Dolayısıyla bireyin nasıl hissettiği, beklentilerinin ne kadarının karşılanabildiği gibi tüm unsurlar söz konusu tanım içinde yer almaktadır.

Öte yandan, mutluluğun belirleyicilerinin neler olduğu üzerine pek çok çalışma yapılmış ve mutluluğun demografik faktörlerle, ekonomik, sosyal, kültürel ve fiziksel çevre koşullarıyla, yaşanılan ülkenin sosyoekonomik koşullarıyla ilişkili bütünsel bir kavram olduğu kabul edilmiştir. Dolayısıyla mutluluk çok sayıda faktörün etkisi altında ortaya çıkan, başka bir deyişle pek çok faktörün bileşimi sonucunda vücut bulan iyi hissetme veya iyilik hâlidir. $\mathrm{Bu}$ açıdan bakıldığında doğrudan yaşamın kendisiyle ilgili pek çok faktöre göre şekillenen mutluluk, yaşam memnuniyetiyle ilişkilendirilmektedir.

Sürdürülen yaşamdan duyulan memnuniyet açısından bakıldığında bireyin yaşam kalitesine yönelik genel değerlendirmesi sonucunda ulaştığı olumluluk derecesi ve duyulan haz, yaşam memnuniyet düzeyini ifade eder. Başka bir deyişle, bireylerin yaşamdan aldıkları hazzın ne derece gerçekleştiği şeklinde tanımlayabileceğimiz yaşam memnuniyetinin sürdürülen yaşam kalitesine bağlı olarak ortaya çıktığı kabul edilmektedir. Bu bağlamda yaşam kalitesi, insanların biyolojik durumları, yaşam biçimleri, ilişkileri ve içinde bulundukları çevrenin 
nicel ve nitel değerlerinin toplamı olarak tanımlanabilir. Bütünsel bir bakış açısıyla değerlendirildiğinde yaşamın tüm boyutlarının üstün nitelikli olması, kaliteli yaşamı olanaklı kılmaktadır.

Yaşam kalitesini tanımlamaya yönelik başlıca iki yaklaşım söz konusudur. $\mathrm{Bu}$ tanımlardan ilki yaşam kalitesini, bireylerin hayat içindeki durumlarını, ait oldukları kültürel yapı ve değerler sistemi bağlamında algılama ve değerlendirme

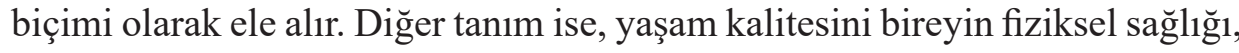
psikolojik durumu, özgürlük seviyesi, sosyal ilişkileri ve yaşadığı çevrenin başlıca özellikleriyle etkileşimi gibi çok sayıda faktöre bağlı olarak şekillenen, karmaşık ve geniş bir kavram olarak nitelendirir.

Ekonomik anlamda refah göstergesi olarak kullanıldığında mutluluk ve yaşam memnuniyeti kavramlarının birbirine çok yakın anlamlar ifade ettiği ve bireylerin genel olarak yaşam kalitelerini değerlendirmeleri sonucunda mutluluk ve yaşam memnuniyeti düzeylerini belirledikleri söylenebilir. Bu açıdan yaşam memnuniyeti ve mutluluk, yaşam kalitesine göre belirlenen iyi oluş hâlidir ve bu iyi oluş hâli aynı zamanda bir refah göstergesi olarak kullanılmaktadır.

$\mathrm{Bu}$ bağlamda, mutluluk ve yaşam memnuniyeti bir refah göstergesi ise ölçemediğiniz şeyi yönetemezsiniz anlayışı uyarınca mutluluk ve yaşam memnuniyetinin nasıl ölçüleceği konusu önem kazanmaktadır.

Mutluluk ve yaşam memnuniyetinin nasıl ölçüleceği konusunda yapılmış çok sayıda çalışma söz konusudur ve Dünya Mutluluk Raporu, Mutlu Gezegen Endeksi bu konuda en çok bilinen çalışmalardır. Ülkemizde de Türkiye İstatistik Kurumu Yaşam Memnuniyeti Araştırması başlığı altında 2003 yılından bu yana her yıl, hane halkı ve fert düzeyinde ülke genelinde araştırmalar gerçekleştirmektedir.

Çalışmamızın konusunu 2019 yılında gerçekleştirilen Yaşam Memnuniyeti Araştırmasının mikro veri seti kullanılarak mutluluk ve yaşam memnuniyeti üzerinde fertlerin demografik özelliklerinin, ekonomik gösterge olarak aylık hane halkı gelir memnuniyeti ve refah düzeyi algısının, sosyal, kültürel ve yaşanılan çevre koşullarının göstergesi olarak sosyal hayat ve konut memnuniyetiyle kendisine ayırabildiği zamandan duyulan memnuniyetin ve bireysel sağliktan duyulan memnuniyeti gösteren değişkenlerinin etkisi ikili lojistik regresyon yöntemiyle analiz edilmesi oluşturmaktadır. 
Bu amaçla yaşam memnuniyetini açıklamak üzere kurulan lojistik regresyon modeline göre, kadınların yaşam memnuniyetinin erkeklere kıyasla daha yüksek olduğu, eğitim düzeyi arttıkça yaşam memnuniyetinin de arttığı, yaş ilerledikçe yaşamdan memnun olma oranının göreceli olarak yükseldiği, algılanan refah seviyesinin de yaşam memnuniyeti üzerinde etkili olduğu ve algılanan refah düzeyine bağlı olarak yaşamdan duyulan memnuniyetin de arttığ Ayrıca, aylık hane halkı gelir memnuniyetinin, yaşanılan konuttan duyulan memnuniyetin, sosyal yaşam memnuniyetinin, bireysel anlamda beden sağlığ1 memnuniyetinin ve fertlerin kendilerine ayırabildiği zamana yönelik duydukları memnuniyetin de yaşam memnuniyet oranını arttırdı̆̆ 1 belirlenmiştir.

Fertlerin yaşam memnuniyetini açıklamak üzere kurulan modelden farklı olarak mutluluğu açıklamak üzere kurulan modelde eğitim değişkeninin fertlerin mutluluğu üzerinde anlamlı bir etkisinin bulunmadığ tespit edilmiştir. Mutluluk için kurulan modele göre, kadınların erkeklere kıyasla daha mutlu oldukları, evli bireylerde mutlu olma oranının bekarlara kıyasla daha fazla olduğu, yaş ilerledikçe mutlu olma oranının genel olarak azaldığı, refah seviyesine yönelik algının mutluluk oranını etkilediği ve refah algısı arttıkça mutlu olma oranının da arttığı anlaşılmaktadır.

Öte yandan, aylık hane halkı gelir memnuniyetinin, yaşanılan konuttan duyulan memnuniyetin, sosyal yaşam memnuniyetinin, bireysel anlamda beden sağlığı memnuniyetinin ve fertlerin kendilerine ayırabildiği zamana yönelik duydukları memnuniyetin de mutluluk oranını arttırdığı belirlenmiştir. Ayrıca söz konusu değişkenlerin mutluluk üzerindeki etkisinin yaşam memnuniyetinden daha fazla olduğu da tespit edilmiştir.

Türkiye İstatistik Kurumu yaşam memnuniyeti araştırmasında hane halk1 düzeyinde uygulanan soru formu 6 ana başlikta toplam 72 sorudan, fert düzeyinde uygulanan soru formu ise 7 ana başlık altında toplanan 246 sorudan oluşmaktadır. Söz konusu araştırmada, çok sayıda soru yer almasına ve yaşama dair çok çeşitli konularda bilgi toplanmasına rağmen mutluluk ve yaşam memnuniyeti birer soru ile ölçülmektedir. Dolayısıyla, araştırma kapsamında mutluluk ve yaşam memnuniyetinin ölçümü ve değerlendirilmesi, diğer tüm sorulardan bağımsız olarak katılımcıların sadece bu iki soruya verdikleri cevaplar üzerinden yapılmaktadır.

Oysa mutluluk ve yaşam memnuniyetini ölçmek üzere katılımcılara birer soru ile mutluluk düzeyini ve yaşam memnuniyetini sormak ve bu yolla toplanan 
cevapları analiz etmek eksik ve yetersiz bir değerlendirmedir. Nitekim çalışma kapsamında da değinildiği gibi, mutluluk ve yaşam memnuniyeti kavramları çok sayıda faktöre bağlı olarak ortaya çıkan ve dolayısıyla yaşama dair pek çok unsuru bünyesinde barındıran bütünleşik kavramlardır. Bu bağlamda mutluluk ve yaşam memnuniyetini ölçmek ancak, bireyin tüm yaşamına yönelik bütünsel bir değerlendirme yapması sonucunda mümkün olabilir. Bu sebeple mutluluk ve yaşam memnuniyetiyle ilgili tüm bileşenleri ölçmek üzere kurgulanmış çok sayıda soru içeren anket formu ile veri toplamak ve tüm veriyi bir bütün olarak değerlendirmek suretiyle her birey için genel bir mutluluk ve yaşam memnuniyeti derecesi belirlemek daha doğru bir yaklaşım olacaktır.

Bu bağlamda Bhutan Krallığı tarafından bütüncül ve sürdürülebilir kalkınma yaklaşımı olarak geliştirilen gayrisafi millî mutluluk kavramı ve gayrisafi millî mutluluğu ölçmek amacıyla kullanılan Gayrisafi Millî Mutluluk Endeksi bir model olarak düşünülebilir.

Nitekim, Birleşmiş Milletler Genel Kurulu, 19 Temmuz 2011 tarihli toplantısı sonrasında yayınladığı "Mutluluk-Kalkınmaya Bütüncül Yaklaşım” başlıklı sonuç belgesinde mutluluğun en temel insan hedefi ve evrensel bir istek olduğunu ve gayrisafi millî hâsılanın yapısı gereği bu hedefi yansıtmadığ belirtilmiş, kalkınma konusunda mutluluğu da kapsayan bütüncül yaklaşımlar benimsenmesine vurgu yapılmıştır.

Birleşmiş Milletlerin mutluluk temelli kalkınma anlayışını salık veren söz konusu açıklaması sonucunda gayrisafi millî mutluluk kavramının bütüncül yaklaşımına ve buna bağlı olarak Gayrisafi Millî Mutluluk Endeksine ilgi artmıştır.

Gayrisafi Mutluluk Endeksinin metodolojisi incelenerek Türk insanının bireysel ve toplumsal özelliklerini göz önüne alan ve içeriğinde eğitimden sağlığa, güvenlikten adalete, aile ilişkilerinden komşuluk ilişkilerine ve hatta sürdürülebilirlik açısından çevre duyarlılığına kadar yaşamın tüm boyutlarını kapsayan soruların kullanıldığı bir bütünleşik ölçme aracı geliştirmek ve mutluluk ve yaşam memnuniyetini tüm bu soruların birlikte değerlendirildiği bütünleşik bir endeks ile ölçmek çok daha kapsamlı, doğru ve sağlıklı bir yaklaşım olacaktır.

Sonuç olarak, Türkiye için özel olarak geliştirilecek gayrisafi mutluluk endeksi, insana yönelik psikolojik iyilik, sağlık, zaman kullanımı, eğitim, 
kültürel çeşitlilik, iyi yönetişim, ekolojik çeşitlilik ve bütünlük, toplumsal canlılık ve yaşam standartları vb. çok sayıda değişkenin birlikte değerlendirildiği bütünleşik bir ölçme aracıyla mutluluk ve yaşam memnuniyetinin ölçülmesi çok daha sağlıklı veri toplamak ve zaman içinde yaşanan değişimi izleme ve uygun kamu politikaları geliştirme açısından son derece önemli bir işlev üstlenecektir.

\footnotetext{
Hakem Değerlendirmesi: Diş bağımsız.

Çıkar Çatışması: Yazar çıkar çatışması bildirmemiştir.

Finansal Destek: Yazar bu çalışma için finansal destek almadığını beyan etmiştir.

Peer-review: Externally peer-reviewed.

Conflict of Interest: The author have no conflict of interest to declare.

Grant Support: The author declared that this study has received no financial support.
}

\section{Kaynakça/References}

Akgiş, Ö. (2015). Bir Refah Göstergesi Olarak Türkiye'de Mutluluğun Mekânsal Dağılışı. Türk Coğrafya Dergisi, (65), 69-76. https://dergipark.org.tr/tr/pub/tcd/ issue $/ 21272 / 228385$

Arslan, İ, Bektaş, H. (2019). Üniversite Öğrencilerinin Yaşam Doyumunun Ölçülmesi. İstanbul Gelişim Üniversitesi Sağllk Bilimleri Dergisi, (8), 767-784. DOI: 10.38079/ igusabder.587380 https://dergipark.org.tr/tr/download/article-file/792279

Aydın, H. (2020). Mutluluk ve Ekonomi: Yaşam Memnuniyeti Araştırması Üzerinden Baz1 Dikkatler. Current Research in Social Sciences, 6(2),135148. DOI:10.30613/curesosc.745642 https://dergipark.org.tr/tr/pub/curesosc/ issue $/ 58004 / 745642$

Bektaş, H. (2015). İkili Değişkenler için Faktör Analizi, Çalışma Yaşamı Kalitesi Üzerine Bir Uygulama, Doktora tezi, İstanbul Üniversitesi Sosyal Bilimler Enstitüsü.

Berberoğlu, C. (2020). Mistik Yalancı. Konya: Atlas Akademi Yayınevi.

Bıçkı, D. (2015). Kentte Yoksulluk Ayrışma ve Yaşam Kalitesi. Bursa: Dora Yayıncılık.

Bozcuk, A. E. ve Öz, Y. (2018). Finansal Durum, Mutluluk ve Umut(suzluk): Üniversite Öğrencilerinde Bir Uygulama. Social Sciences Studies Journal, 4(23), 4731-4741

Chow, H. P. H. (2005). Life Satisfaction among University Students in a Canadian Prairie City: A Multivariate Analysis. Social Indicators Research, 70, 139-150

Çevik, N. K., Altınkeski, B. K. ve Kantarc1, T. (2019). Mutlu Gezegen Endeksi: Dünyanın En Mutlu Ülkelerinden Panel Veri Bulguları, Iğdır Üniversitesi Sosyal Bilimler Dergisi, Ek Say1, Aralık, 81-201. http://sosbilder.igdir.edu.tr/Makaleler/954712396_09Mak-181-201.pdf

Dalia A. and Juozas R. (2007). Quality of Life and its Components' Measurement. Engineering Economics, 2(52). 
Diener, E., Oishi, S., \& Lucas, E. R. (2003). Personality, Culture, and Subjective WellBeing Emotional and Cognitive Evaluations of Life. Annual Review of Psychology, 54, 403-425.

Diener E., Emmons R., Larsen R.J, Griffin S. (1985). The Satisfaction with Life Scale. Journal of Personality Assessment, 49(1), 71-75.

Diener E. (1984). Subjective Well-Being. Psychological Bulletin. 95(3): 542-575.

Dockery, A. M. (2003). Happiness, Life Satisfaction and The Role of Work: Evidence from Two Australian Surveys, Paper Presented at 10th National Conference on Unemployment, 10-12 December, Newcastle, UK

https://melbourneinstitute.unimelb.edu.au/assets/documents/hilda-bibliography/ working-discussion-research-papers/2001-2004/Dockery_happiness_life_ satisfaction.pdf

Gujarati, D. Çev: Bolatoğlu, N. (2016). Örneklerle Ekonometri, BB101 Yayını, Ankara.

Güneş, B., Taş, İ., Acar, S. (2020). Türkiye'de İllerin Mutluluğu. Ankara Üniversitesi SBF Dergisi, 75(2), 747-774. https://doi.org/10.33630/ausbf.662294

Karabulut, G. (2017). Mutluluk ve İktisat. İstanbul: Derin Yayınlar1.

Karagöz, Y. (2015). SPSS 22 Uygulamalı Biyoistatistik, Güncellenmiş 2. Basım, Nobel Yayınevi, Ankara.

Oktay, D. (2007). Sürdürülebilirlik, Yaşanabilirlik ve Kentsel Yaşam Kalitesi. Mimarlık Dergisi, 335, Mayıs-Haziran, http://www.mimarlikdergisi.com/index.cfm?sayfa= mimarlik\&DergiSayi=53\&RecID=13 29, Çevrimiçi: 05.07.2021.

Parlak, B. (2011). "Yaşanabilir Bir Samsun: Kentsel Yaşanabilirlik Analizi”, Samsun Sempozyumu, 13-16 Ekim, Samsun.

Şeker, M. (2011). Mutluluk Ekonomisi. Istanbul Journal of Sociological Studies, 0 (39), 115-140. https://dergipark.org.tr/tr/pub/iusoskon/issue/9511/118860

Şeker, M. (2016). Mutluluk Ekonomisi, -kamu ekonomisi açısından bir analiz-. İstanbul: Türkmen Kitabevi.

Şeker, M. ve Bektaş, H. (2019). Mutluluğu Etkileyen Demografik Faktörler, Adı: MutlulukFarklı Disiplinlerden Mutluluk Kavramına Bakış. İstanbul: Çınaraltı Yayın Dağıtım.

Tandoğan O. (2014). Çocuk için daha yaşanılır bir kentsel mekân: Dünyada gerçekleştirilen uygulamalar. Megaron, 9(1), 19-33. https://jag.journalagent.com/megaron/pdfs/ MEGARON-43534-ARTICLE-TANDOGAN.pdf Çevrimiçi: 05.07.2021.

Tıraş, H. (2019). Türkiye İçin İnsani Gelişmişlik Göstergeleri. Bilgi Ekonomisi ve Yönetimi Dergisi, 14(1), 15-31.

https://dergipark.org.tr/tr/pub/beyder/issue/46315/558111

TÜİK Yaşam Memnuniyeti Araştırması Mikro Veri Seti-2020, Yayın No: 4618, Mayıs 2021, https:/www.tuik.gov.tr/media/microdata/pdf/yasam-memnuniyeti-arst.pdf

Uludağ, O. (2016). Mutluluk Ülkesi Bhutan, Magma Dergisi, 21 Ekim 2016, Çevrimiçi: 20.07.2021 https://magmadergisi.com/seyahat-onerileri/mutluluk-ulkesi-bhutan 
Ulutürk Akman, S. (2011). Tüketicilerin Fiyat Bilinci Üzerinde Etkili Olan Faktörlere İlişkin Bir İnceleme. Maliye Araştırma Merkezi Konferanslarl, 0 (46), https:// dergipark.org.tr/tr/pub/iumamk/issue/744/8029

UlutürkAkman, S, Bektaş, H. (2017). Üniversite Öğrencilerinin Demografik Özelliklerinin Girişimcilik Eğilimleri Üzerindeki Etkileri. Siyaset, Ekonomi ve Yönetim Araştırmaları Dergisi, 5(2), 309-318.

https://dergipark.org.tr/tr/pub/seyad/issue/53371/709577

Vatansever Deviren, N, Yıldız, O. (2017). Gayrisafi Millî Mutluluğun Ekonomik Kalkınmadaki Rolü: Bhutan Krallı̆̆ Örneği. Adnan Menderes Üniversitesi Sosyal Bilimler Enstitüsü Dergisi, 4(4), 232-248.DOI: 10.30803/adusobed.356003, https://dergipark.org.tr/tr/pub/adusobed/issue/33430/356003

Veenhoven, R. (1989). (a) Conditions of Happiness, Second Edition, Holland, D. Reidel Publishing Company.

Veenhoven, R. (1996), “The Study o f Life Satisfaction” (Ed.: W.E. Saris, R. Veenhoven, A.C. Scherpenzeel ve B.A. Bunting), Comparative Study of Satisfaction with Life in Europe, Eötvös University Press. 
